\title{
BIOGEOCHEMICAL CYCLING OF PHOSPHORUS: INSIGHTS FROM OXYGEN ISOTOPE EFFECTS OF PHOSPHOENZYMES
}

\author{
RUTH E. BLAKE*' ${ }^{\dagger}$, JAMES R. O’NEIL** and ALEKSANDR V. SURKOV*
}

\begin{abstract}
Geochemical cycling of phosphorus $(\mathrm{P})$ in aquatic environments is carried out almost exclusively by biota and involves reactions that are catalyzed by enzymes. Oxygen isotope effects accompanying phosphoenzymatic reactions have been determined in controlled laboratory experiments in order to elucidate processes underlying biogeochemical cycling of $P$, and to identify possible reaction pathways for P-compounds in nature. Phosphate oxygen isotope effects are distinct for specific enzymatic reaction mechanisms measured in microbial culture experiments and in cell-free systems. $\mathrm{P}^{16} \mathrm{O}_{4}$ is taken up preferentially from inorganic phosphate $\left(\mathrm{P}_{\mathrm{i}}\right)$ in the growth medium by intact $E$. coli cells, producing a kinetic fractionation in the extracellular dissolved $P_{i}$ pool. Inorganic pyrophosphatase is the intracellular enzyme that catalyzes the temperature-dependent equilibrium oxygen isotope fractionations between phosphates and water in biological systems, and imprints an equilibrium isotope signature on $P_{i}$ that is turned over or cycled by intact cells. Alkaline phosphatase, a key enzyme involved in extracellular $P_{i}$ regeneration in aquatic systems, catalyzes hydrolysis of phosphomonoesters, reactions that are accompanied by kinetic fractionations and disequilibrium (inheritance) isotope effects in released $\mathrm{P}_{\mathrm{i}}$. Comparison of laboratory determined enzyme-specific isotopic fractionations with those observed in microbial culture experiments and in natural aquatic systems, provide new insights into processes controlling $\mathbf{P}$ cycling and the relations between $\mathbf{P}$ availability and the cycling of $\mathbf{N}$ and $\mathbf{C}$. Isotopic signatures associated with specific cellular processes and phosphoenzyme reaction pathways may be useful in assessing $P$ status and for tracing $P$ turnover.
\end{abstract}

\section{Definition of Symbols and Abbreviations}

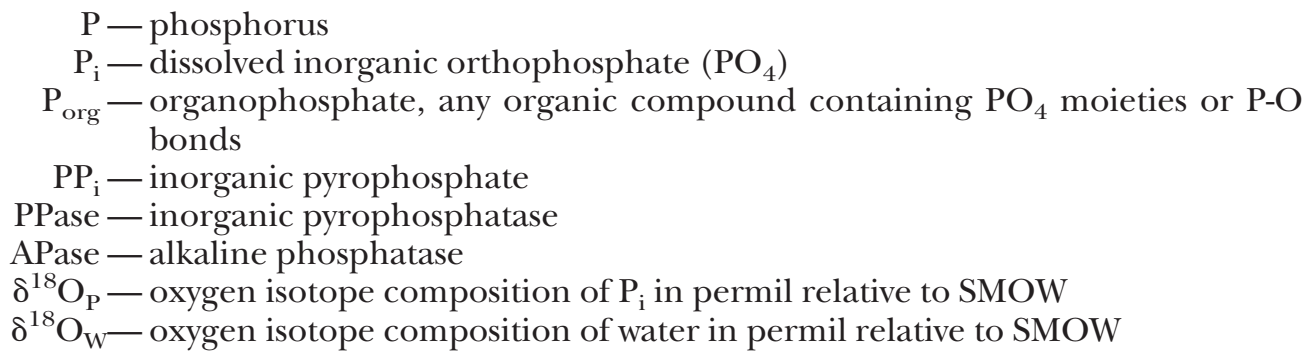

INTRODUCTION

Phosphorus $(\mathrm{P})$ is a constituent of several important biomolecules in living organisms including ATP (energy source), RNA and DNA (information storage) and phospholipids (structural support). The availability of dissolved inorganic phosphate $\left(\mathrm{P}_{\mathrm{i}}\right)$ limits primary biological productivity in many freshwater systems and in oligotrophic regions of the ocean where dissolved organic phosphorus $\left(\mathrm{P}_{\text {org }}\right)$ compounds can become the dominant sources of $\mathrm{P}$ (Smith and others, 1986; Karl and Yanagi, 1997; Clark and others, 1998, 1999; Kolowith and others, 2001; Karl and Bjorkman, 2002). The enzymes that catalyze regeneration of $\mathrm{P}_{\mathrm{i}}$ from organic matter and release of $\mathrm{P}_{\mathrm{i}}$ from $\mathrm{P}_{\text {org }}$ thus play a critical role in $\mathrm{P}_{\mathrm{i}}$ availability and biogeochemical cycling of $\mathrm{P}$ in

*Department of Geology and Geophysics, Yale University, P.O. Box 208109, New Haven, Connecticut 06520-8109

**Department of Geological Sciences, University of Michigan, Ann Arbor, Michigan 48109

†Corresponding author: ruth.blake@yale.edu 
aquatic systems. The cycling of carbon $(\mathrm{C})$ is also linked to $\mathrm{P}$ cycling as the metabolism of many carbon substrates requires $\mathrm{P}_{\mathrm{i}}$ co-transport and activation by phosphorylation (Maloney, 1992; van Veen, 1997). The process of active nitrogen (N) fixation has also been shown to require P, and therefore can become P limited (Sañudo-Wilhelmy and others, 2001; Krom and others, 2004).

Biochemical reactions of $\mathrm{P}$ at the cellular/molecular level have been studied intensively and elucidated in great detail. Nonetheless, we have no detailed understanding of reaction mechanisms during biogeochemical cycling of $\mathrm{P}$ in natural aquatic systems at the present time due partly to a lack of suitable tracers and methods of analysis for P (Benitez-Nelson, 2000; Karl, 2000). Important advances have been made using ${ }^{31} \mathrm{P}-\mathrm{NMR}$ techniques and measurements of the cosmogenic radionuclides ${ }^{32} \mathrm{P}$ and ${ }^{33} \mathrm{P}$ to quantify dissolved and sedimentary $\mathrm{P}$ species and to study transformations of $\mathrm{P}$ in marine systems (Benitez-Nelson and Buesseler, 1999; Clark and others, 1999; Larkaamp, ms, 2000; Paytan and others, 2003). Challenges to tracing biogeochemical reactions of $\mathrm{P}$ versus other macro-nutrients like $\mathrm{C}, \mathrm{N}$ and $\mathrm{S}$ stem in part from the unique chemical properties of $\mathrm{P}$ which occurs in nature predominantly as orthophosphate $\left(\mathrm{PO}_{4}\right.$ or $\left.\mathrm{P}_{\mathrm{i}}\right)$, has no significant gas phase, and has only one stable isotope, ${ }^{31} \mathrm{P}$. Moreover, unlike $\mathrm{C}, \mathrm{N}$, and $\mathrm{S}$, which occur in variable oxidation states that may be used to trace reactions, $\mathrm{P}$ occurs almost exclusively in the +5 oxidation state. The notion that $\mathrm{P}$ has no redox chemistry has been challenged recently by the discovery and isolation of organisms that readily utilize reduced-P compounds (phosphite, hypophosphite) as a source of $\mathrm{P}$ (Metcalf and Wolf, 1998), and of a $\mathrm{SO}_{4}$-reducing bacterium capable of dissimilatory oxidation of phosphite, $\left(\mathrm{PO}_{3}\right)^{3-}$ in normal marine sediments (Schink and Friedrich, 2000; Schink and others, 2002).

The four oxygen atoms surrounding the central $\mathrm{P}$ atom in $\mathrm{PO}_{4}$ comprise three stable isotopes ${ }^{16} \mathrm{O},{ }^{17} \mathrm{O}$ and ${ }^{18} \mathrm{O}$ whose natural distributions provide a potential means of distinguishing different biogeochemical pathways and tracing chemical reactions of $\mathrm{PO}_{4}$ in aquatic systems. It has been suggested that the oxygen isotope composition of $\mathrm{P}_{\mathrm{i}}$ $\left(\delta^{18} \mathrm{O}_{\mathrm{P}}\right)$ may be a useful tracer of biogeochemical cycling of $\mathrm{P}$ (Blake and others, 1997, 1998a; Colman, ms, 2002; Paytan and others, 2002; McLaughlin and others, 2004).

The use of $\delta^{18} \mathrm{O}_{\mathrm{P}}$ as a geochemical indicator has intensified in recent years as a result of improved analytical techniques (O'Neil and others, 1994; Sharp and Cerling, 1996; Vennemann and others, 2002). Applications of $\delta^{18} \mathrm{O}_{\mathrm{P}}$ measurements thus far have been limited primarily to biogenic apatite in mammalian teeth and bones, fish scales and shells in order to place constraints on environmental/temperature conditions under which biogenic phosphate minerals form (Longinelli and Nuti, 1973; Kolodny and others, 1983; Longinelli, 1984; Luz and Kolodny, 1985; Fricke and O'Neil, 1996; Lécuyer and others, 1996). It has been shown that biogenic apatite forms in or near oxygen isotopic equilibrium with body (cellular) water as a result of multiple enzyme-catalyzed hydrolytic cleavage, condensation, and phosphoryl-group transfer reactions inside of cells that lead to equilibrium isotopic exchange between $\mathrm{P}_{\mathrm{i}}$ and water (Longinelli and Nuti, 1973; Luz and Kolodny, 1985; Lécuyer and others, 1996). As an essential and often limiting macro- nutrient, $\mathrm{P}$ is subject to intense biological cycling such that reactions of $\mathrm{P}$ compounds in aquatic environments are dominated by biota and catalyzed by the enzymes they produce. In contrast to biogenic phosphates where the exchange of $\mathrm{P}_{\mathrm{i}}$ with body fluids and subsequent precipitation as apatite occurs within a tightly closed system (inside the organism), the metabolism of $\mathrm{P}_{\mathrm{i}}$ in natural waters and sediments is carried out largely by microorganisms, algae and plants in relatively open systems, and involves intracellular-extracellular exchange of $\mathrm{P}_{\mathrm{i}}$ across cellular membranes (fig. 1; Maloney, 1992; van Veen, 1997; Blake and others, 1998a). Thus, the extracellular $\mathrm{P}_{\mathrm{i}}$ pool is affected by enzyme-mediated processes that occur both inside and outside of the cell. 


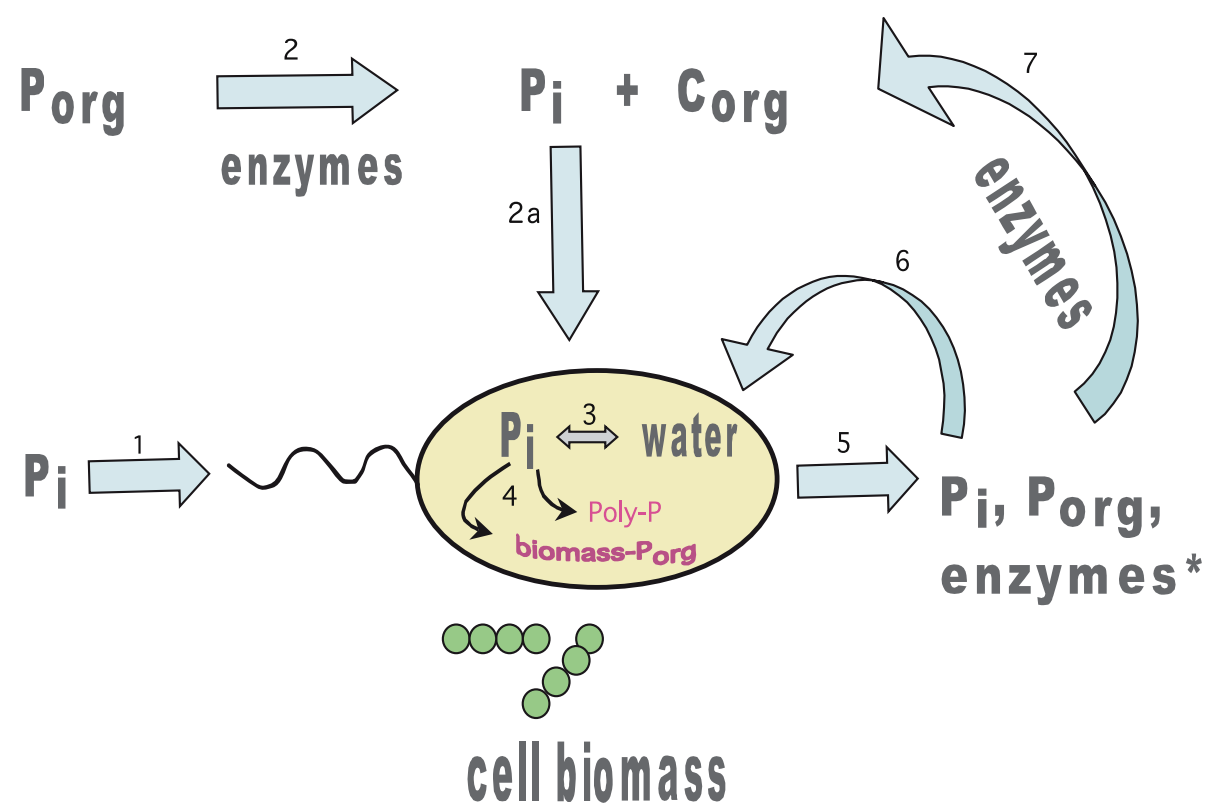

Fig. 1. Biogeochemical cycling of $\mathrm{P}$ in aquatic systems. (1) direct uptake of free $\mathrm{P}_{\mathrm{i}}$ by diffusion, enzymes not required; (2) extracellular enzymatic hydrolysis of $\mathrm{P}_{\text {org }}$ to release $\mathrm{P}_{\mathrm{i}}+\mathrm{C}_{\text {org }}$ (2a) subsequent uptake of $\mathrm{P}_{\mathrm{i}}$ derived form $\mathrm{P}$ facilitated by membrane-bound transport proteins; (3) intracellular $\mathrm{P}_{\mathrm{i}}$-water $\mathrm{O}$ isotope exchange catalyzed by various enzymes; (4) incorporation of $\mathrm{P}_{\mathrm{i}}$ into $\mathrm{P}_{\text {org }}$ compounds in biomass (for example, RNA phospholipids); (5) release of intracellular $\mathrm{P}_{\mathrm{i}}, \mathrm{P}_{\text {org }}$ and enzymes* from cells during growth or following death/lysis; (6) $\mathrm{P}_{\mathrm{i}}$ recycling via re-uptake of intracellularly cycled $\mathrm{P}_{\mathrm{i}}$; (7) recycling of $\mathrm{P}_{\text {org }}$. Many of the pathways for P cycling involve enzyme catalysis.

\section{Biogeochemical Cycling of $P$}

Use of $\delta^{18} \mathrm{O}_{\mathrm{P}}$ as a tracer of biogeochemical $\mathrm{P}$ cycling requires detailed characterization of the oxygen isotope effects attendant on the reactions that take place in such cycling. Figure 1 depicts major processes that occur during $\mathrm{P}$ cycling in aquatic environments: enzymatic release of $\mathrm{P}_{\mathrm{i}}$ from $\mathrm{P}_{\text {org }}$, uptake and metabolism of $\mathrm{P}_{\mathrm{i}}$ by biota, exudation of $\mathrm{P}_{\mathrm{i}}$ by cells, and regeneration of $\mathrm{P}_{\mathrm{i}}$ from decaying biomass. Phosphate may also be removed from the dissolved phase by adsorption to surfaces of solids such as Feor Al-oxides, or precipitation as apatite. Most of the processes depicted in figure 1 are catalyzed by phosphoenzymes and should be accompanied by oxygen isotope effects. Knowledge of these isotopic effects is critical to understanding controls on $\delta^{18} \mathrm{O}_{\mathrm{P}}$ values of naturally occurring substances and may allow detection and characterization of the transformations and biological utilization of specific P compound classes (for example, phosphomonoesters) by biota during P cycling. An understanding of these controls will also allow us to make meaningful interpretations of $\delta^{18} \mathrm{O}_{\mathrm{P}}$ in extraterrestrial materials (for example, from Mars) that are currently being explored for evidence of water and biological activity, and targeted for sample return missions in the future.

Very few measurements have been made of the oxygen isotope composition of $\mathrm{P}_{\mathrm{i}}$ in natural systems. Longinelli and others (1976) reported temperature independent disequilibrium, $\mathrm{PO}_{4}$-water fractionations for dissolved inorganic phosphate in seawater and $\mathrm{P}_{\mathrm{i}}$ extracted from soft tissues of marine invertebrates. Paytan and others (2002) reported similar results for analyses of seawater $\mathrm{P}_{\mathrm{i}}$ and $\mathrm{P}_{\text {org }}$ from tissues of cultured marine algae. Blake and others (1997) and Colman (ms, 2002) suggested that earlier studies by Paytan and others (2002) and Longinelli and others (1976) were likely 
impacted by sample storage and /or analytical artifacts. Specifically, the samples used in the pioneering work of Longinelli and others (1976) were not initially collected for $\delta^{18} \mathrm{O}_{\mathrm{P}}$ analysis, and thus they were not stored optimally for this analysis (Colman, ms, 2002). Most importantly, no measures were taken to prevent post-sampling biological/ enzymatic activity (samples stored aboard ship with no refrigeration or treatment with bactericides). Thus, $\delta^{18} \mathrm{O}_{\mathrm{P}}$ values may have been altered or reset from initial deep sea values to those reflecting ambient ship deck conditions. Sample handling protocols were not detailed by Paytan and others (2002), but in both this study and that of Longinelli and others (1976) strong acid hydrolysis was used to process unpurified samples containing a mixture of inorganic and organically-bound phosphates (phosphoesters). This treatment certainly caused incorporation of water from the medium during P-O bond hydrolysis (Blake and others, 1997; Liang, ms, 2005). The relative amounts of organic and inorganic phosphates as well as $\delta^{18} \mathrm{O}$ values of water used in acid solutions were not reported by these authors and so the extent of any effect due to incorporation of water during hydrolysis of P-O bonds (for example, phosphoesters, polyphosphate) cannot be easily evaluated. The effect of such incorporation would be to mask isotopic and temperature effects and offset $\delta^{18} \mathrm{O}_{\mathrm{P}}$ values of in-situ $\mathrm{P}_{\text {org }}$ (Liang, ms, 2005).

Oxygen isotope systematics of $\mathrm{PO}_{4}$ during microbial metabolism of $\mathrm{P}_{\mathrm{i}}$ and $\mathrm{P}_{\text {org }}$ were studied in experiments using intact microbial cells as a source of phosphoenzymes (alkaline phosphatase, nucleotidase) to regenerate $\mathrm{P}_{\mathrm{i}}$ from $\mathrm{P}_{\text {org }}$ in nucleic acids and phosphosugars and to cycle $\mathrm{P}_{\mathrm{i}}$ in the growth medium (Blake and others, 1997, 1998a). These were complex experimental systems with multiple superimposed processes acting on the phosphate pool to produce the $\delta^{18} \mathrm{O}_{\mathrm{P}}$ signatures observed. Nevertheless, consistent trends in isotopic fractionations were observed. As discussed below, microbial metabolism of $\mathrm{P}_{\text {org }}$ compounds such as RNA and glucose-1-phosphate requires extracellular release of $\mathrm{P}_{\mathrm{i}}$ by enzymes (fig. 1).

\section{BACKGROUND}

The preferred form of $\mathrm{P}$ for biological utilization is $\mathrm{P}_{\mathrm{i}}$ which is taken up readily by microbial cells, plants and algae. Other inorganic $\mathrm{P}$ species such as pyrophosphate and polyphosphates are also utilized by biota, as well as selected small $\mathrm{P}_{\text {org }}$ compounds like glycerol- $\mathrm{PO}_{4}$ and ribose- $\mathrm{PO}_{4}$ which may be transported directly by some cells through specialized proteins in the cytoplasmic membrane (Torriani-Gorini and others, 1994). The high demand for $\mathrm{P}$ leads to rapid depletion of $\mathrm{P}_{\mathrm{i}}$ and results in the characteristically low phosphate concentrations that are observed in freshwater and marine environments. Conditions of $\mathrm{P}_{\mathrm{i}}$-limitation persist in many lakes, in parts of the oligotrophic Atlantic and Pacific oceans (Cotner and others, 1997; Karl and Yanagi, 1997; Wu and others, 2000; Bjorkman and Karl, 2003), and in the Eastern Mediterranean Sea (Krom and others, 2004). The availability of P also exerts a strong control on the utilization of carbon and nitrogen which, in turn, affects overall biological productivity, burial of organic carbon, and the levels of $\mathrm{O}_{2}$ and $\mathrm{CO}_{2}$ in the atmosphere (Broecker and Peng, 1982; Sundareshwar and others, 2003). Notably, while primary production by autotrophs may be largely N-limited, the growth of $\mathrm{N}$-fixing bacteria may be limited by the availability of P (Sundareshwar and others, 2003).

\section{Microbial P Metabolism and Phosphoenzymes}

Bioavailability of P.-Under conditions of limited $\mathrm{P}_{\mathrm{i}}$, a series of geneticallycontrolled reactions is initiated which allows microorganisms to utilize more recalcitrant $\mathrm{P}_{\text {org }}$ compounds such as nucleic acids, phosphosugars and phospholipids as a source of $\mathrm{P}_{\mathrm{i}}$ for growth. This cascade of genetic responses is controlled by the Pho regulon region of the bacterial chromosome, which is activated by low environmental $\mathrm{P}_{\mathrm{i}}$ concentrations (Torriani-Gorini and others, 1994). In order for organisms to utilize 
most $\mathrm{P}_{\text {org }}$ compounds, specialized transport proteins and enzymes, the so-called phosphate-scavenging enzymes, must be synthesized and employed to break down large and complex $\mathrm{P}_{\text {org }}$ molecules into smaller units and release organically-bound $\mathrm{PO}_{4}$ as free $\mathrm{P}_{\mathrm{i}}$. These enzymes, most notably alkaline phosphatase (APase), $5^{\prime}$-nucleotidases and phosphodiesterases, catalyze hydrolysis of phosphoester bonds in phosphomonoesters (ATP, sugar- $\mathrm{PO}_{4}$, polyphosphates), and phosphodiesters (RNA, DNA), and belong to the class of enzymes called phosphohydrolases (Walsh, 1979; Ammerman, 1991). Phosphohydrolases are common to natural waters and sediments where they are involved in the degradation of organic matter and regeneration of $\mathrm{P}_{\mathrm{i}}$ to the water column (Ammerman and Azam, 1985; Feuillade and Dorioz, 1992; Siuda and Güde, 1994; Hoppe and Ulrich, 1999). Hydrolysis of most $\mathrm{P}_{\text {org }}$ compounds occurs extracellulary, that is, outside of the cell cytoplasm, either in the periplasmic space located between the outer cell wall and cytoplasmic membrane of gram negative bacteria, or completely external to the cell in the surrounding medium. $\mathrm{P}_{\mathrm{i}}$ is taken up by cells and transported into the cytoplasm by diffusion, or via facilitated transport processes carried out by ATP-driven pumps and transport proteins embedded within the cytoplasmic membrane (Maloney, 1992; van Veen, 1997; fig. 2 in Blake and others, 1998a).

Intracellular reactions of $P$. - Once inside the cell, $\mathrm{P}_{\mathrm{i}}$ is further subject to a number of metabolic reactions including incorporation into cell biomass, transfers during ATP utilization, and signal transduction via phosphorylation/dephosphorylation reactions (fig. 1). All of these intracellular $\mathrm{P}$ reactions involve catalysis by enzymes and it is generally assumed that intracellular enzymatic reactions of $\mathrm{P}_{\mathrm{i}}$ lead to the oxygen isotope equilibrium observed between $\mathrm{P}_{\mathrm{i}}$ in biogenic phosphates (bones, teeth, shells) and water (that is, body fluids, ambient water) (Longinelli and Nuti, 1973; Luz and Kolodny, 1985; Lécuyer and others, 1996).

The isotope effects of extracellular phosphate-scavenging enzymes and any isotopic fractionation accompanying uptake of extracellular $\mathrm{P}_{\mathrm{i}}$ will be overprinted by subsequent reactions inside the cell. Similarly, when cells die, biomass $\mathrm{PO}_{4}$ that is bound in $\mathrm{P}_{\text {org }}$ is released back to the extracellular medium as $\mathrm{P}_{\mathrm{i}}$, again due to the action of phosphate-scavenging enzymes. Thus, regenerated $\mathrm{P}_{\mathrm{i}}$ will have a $\delta^{18} \mathrm{O}_{\mathrm{P}}$ value that is overprinted by fractionations associated with enzymatic $\mathrm{P}_{\mathrm{i}}$ regeneration reactions. For example, $\mathrm{P}_{\mathrm{i}}$ regenerated from phosphoesters in microbial cultures under conditions of high $\mathrm{P}$ concentration $(90-140 \mathrm{mM})$ appears to retain or inherit oxygen from the phosphoester source as well as acquire oxygen from ambient water during enyzmatic hydrolysis (Blake and others, 1997, 1998a; Liang, ms, 2005).

Many cells expel intracellular phosphate during active growth and, under certain growth conditions, $\mathrm{P}_{\mathrm{i}}$ may be stored inside of cells in the form of polyphosphates which are subsequently degraded releasing $\mathrm{P}_{\mathrm{i}}$ to the extracellular environment (Nawrocki and Karl, 1989; Maloney, 1992; van Veen, 1997; Hellweger and others, 2003). Lysis of microbial cells, due either to virus/predator activity or cell death and autolysis, also releases both intracellular $\mathrm{P}$ and intracellular enzymes into the ambient environment (fig. 1). Furthermore, intracellular enzymes released to the extracellular medium could retain catalytic activity and promote $\mathrm{P}_{\mathrm{i}}$-water exchange. Thus, intracellular as well as extracellular phosphoenzymes may be involved in $\mathrm{P}$ cycling and play a role in determining the $\delta^{18} \mathrm{O}$ value of the $\mathrm{P}_{\mathrm{i}}$ pool in aquatic systems. This potentially complex scenario makes interpretation of $\delta^{18} \mathrm{O}_{\mathrm{P}}$ challenging. On the other hand, dominance by one process or enzymatic pathway greatly simplifies the system. Under such conditions, useful insights into details of $\mathrm{P}$ cycling could be made from measurements of $\delta^{18} \mathrm{O}_{\mathrm{P}}$.

Inorganic pyrophosphatase. - Although a variety of enzymes catalyze $\mathrm{P}_{\mathrm{i}}$-water exchange during metabolism of $\mathrm{P}$ compounds inside cells, one enzyme, inorganic pyrophosphatase (PPase), is an ubiquitous intracellular enzyme that is highly con- 

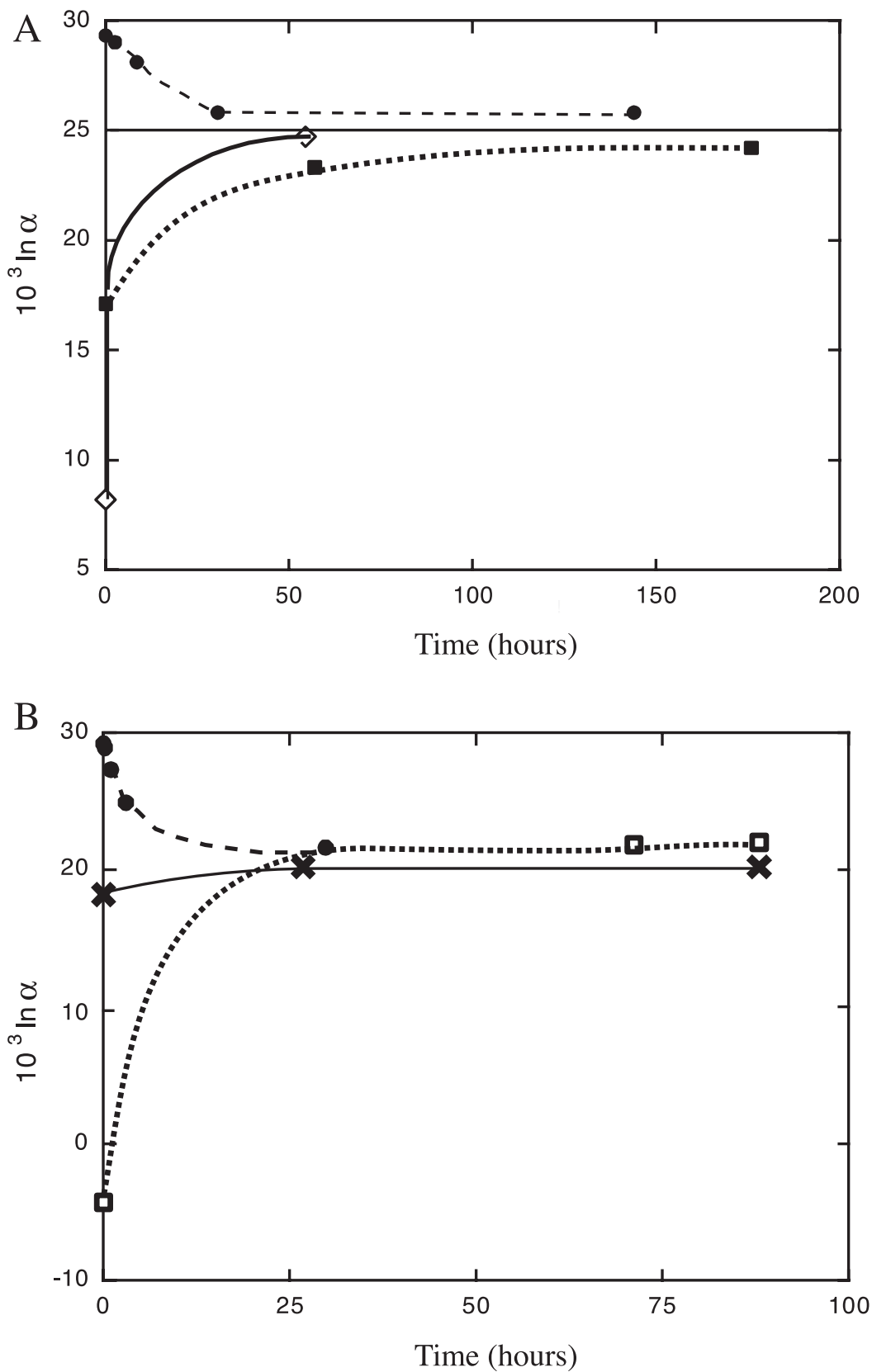

Fig. 2. Results of inorganic pyrophosphatase experiments. Rapid, $\mathrm{PO}_{4}$-water $\mathrm{O}$ isotope exchange catalyzed by cell-free inorganic pyrophosphatase (PPase) and approach to equilibrium fractionation (that is, $\left.\delta^{18} \mathrm{O}_{\mathrm{p}-} \delta^{18} \mathrm{O}_{\mathrm{W}}\right)$ from opposite directions at (A) $5.7^{\circ} \mathrm{C}$ in $-19.5(\mathbf{O}),-7.4(\boldsymbol{\square})$, and $+1.4(\diamond)$ permil waters, and (B) $22^{\circ} \mathrm{C}$ in $-19.4(\mathbf{O}),-8.5(\boldsymbol{*})$ and $+14.0(\diamond)$ permil waters. Note experiment beginning very near equilibrium and remaining constant with time (*'s).

served across all three domains of life: Bacteria, Eukarya, and Archaea (Kunitz, 1951; Cooperman and others, 1992: Pohjanjoki and others, 1998; Leppanen and others, 1999). PPase catalyzes the hydrolytic cleavage of pyrophosphate $\left(\mathrm{PP}_{\mathrm{i}}\right)$ into two $\mathrm{PO}_{4}$ 
molecules. $\mathrm{PP}_{\mathrm{i}}$ is derived from numerous metabolic pathways involving ATP, and cleavage of the high-energy $\mathrm{P}$ bond in $\mathrm{PP}_{\mathrm{i}}$ by $\mathrm{PPase}$ provides energy to drive energetically unfavorable cellular reactions. Without $\mathrm{PP}_{\mathrm{i}}$ hydrolysis by $\mathrm{PPase}$, intracellular $\mathrm{PP}_{\mathrm{i}}$ concentrations would rise to lethal levels (Chen and others, 1990). The pool of intracellular dissolved $\mathrm{P}$ is highly dynamic due to rapid turnover of phosphatic biomolecules such as RNA, and constant consumption/synthesis of ATP during active growth. Microbial cells maintain relatively high and constant concentrations of intracellular $\mathrm{P}_{\mathrm{i}}(11-30 \mathrm{mM})$ regardless of the concentration of extracellular $\mathrm{P}_{\mathrm{i}}$, in order to sustain a condition of cellular homeostasis (Rosenberg and others, 1982). Inorganic pyrophosphatase was targeted for initial oxygen isotope studies of intracellular phosphoenzymes because it occurs freely dissolved in the cytoplasm and uses intracellular $\mathrm{P}_{\mathrm{i}}$ as well as $\mathrm{PP}_{\mathrm{i}}$ as a substrate. We hypothesize that, regardless of the intracellular metabolic pathways employed by $\mathrm{P}_{\mathrm{i}}$ during incorporation into biomass, PPase is involved. That is, whenever $\mathrm{P}_{\mathrm{i}}$ passes through the cytoplasmic $\mathrm{P}_{\mathrm{i}}$ pool, it is subject to the action of PPase. PPase is therefore expected to exert a strong influence on the isotopic composition of intracellular dissolved $\mathrm{P}_{\mathrm{i}}$.

There is another reason for targeting this enzyme for study. In her pioneering research on the PPase reaction mechanism, Cohn (1953) observed highly reversible character, which suggested the possibility of equilibrium isotope exchange between $\mathrm{P}_{\mathrm{i}}$ and water catalyzed by PPase. By contrast, the well known hydrolytic reaction of alkaline phosphatase (APase) is strongly unidirectional in character and, therefore, is expected to produce kinetic isotope effects. Thus, PPase was chosen as the most likely phosphoenzyme to catalyze reactions that occur within the intracellular environment, and as the best candidate for imprinting the equilibrium oxygen isotope signature on $\mathrm{P}_{\mathrm{i}}$ that has been observed both in previous experiments on microbial $\mathrm{P}$ metabolism (Blake and others, 1997, 1998a), and in biogenic apatites of bones, teeth and shells (for example, Luz and Kolodny, 1985; Fricke and O'Neil, 1996; Lécuyer and others, 1996).

Extracellular phosphate-scavenging enzymes.-Alkaline phosphatase (APase) was chosen as a representative enzyme involved in extra-cytoplasmic release of $\mathrm{P}_{\mathrm{i}}$ from phosphomonoesters, the most abundant species in the dissolved $\mathrm{P}_{\text {org }}$ pool of natural waters (Karl and Yanagi, 1997; Clark and others, 1998; Benitez-Nelson, 2000; Karl and Bjorkman, 2002). The oxygen isotope effects of $5^{\prime}$-nucleotidase, another common phosphomonoesterase involved in $\mathrm{P}_{\mathrm{i}}$ regeneration in coastal marine waters (Ammerman and Azam, 1985), was studied in our laboratory at Yale and results will be reported separately (Liang and Blake, 2002; Liang, ms, 2005).

Determination of the isotopic signatures associated with PPase and other specific enzymatic reactions of $\mathrm{PO}_{4}$ will allow interpretation of $\delta^{18} \mathrm{O}_{\mathrm{P}}$ values from natural aquatic systems and further development of $\delta^{18} \mathrm{O}_{\mathrm{P}}$ as a tracer of biogeochemical cycling of $\mathrm{P}$.

\section{METHODS}

Natural environments and even laboratory systems that contain pure cultures of microorganisms, are complicated by the myriad simultaneous and superimposed processes that may contribute to the fractionation of oxygen isotopes in systems containing $\mathrm{PO}_{4}$. Technology currently available limits our ability to study individual processes occurring inside of cells and to measure their associated oxygen isotope effects directly. Another challenge to such studies is the occurrence of $\mathrm{P}$ in the same chemical form $\left(\mathrm{P}_{\mathrm{i}}\right)$ before and after cycling through cells, making it difficult to distinguish reacted from unreacted phosphate in the extracellular $\mathrm{P}_{\mathrm{i}}$ pool. In the present study, experimental systems were designed to represent the simplest possible analogues of enzyme-catalyzed reactions and to isolate specific processes (cellular $\mathrm{P}_{\mathrm{i}}$ uptake) occurring in microbial cultures and natural waters, so that the oxygen isotope 
effects associated with only one process could be determined, one process at a time. The overall goal of these experiments was to link specific processes, such as cellular $P_{i}$ uptake, intracellular $\mathrm{P}$ cycling, and extracellular $\mathrm{P}_{\mathrm{i}}$ regeneration, with specific oxygen isotope effects.

Intracellular enzyme reactions.-PPase was obtained commercially (Sigma ${ }^{\mathrm{TM}}$ \#1403) and prepared according to manufacturer instructions. The experimental system comprised equimolar amounts of $\mathrm{P}_{\mathrm{i}}\left(\right.$ as $\left.\mathrm{KH}_{2} \mathrm{PO}_{4}\right)$ and $\mathrm{Mg}^{2+}$ (as $\mathrm{MgCl}_{2}$ ) between 5 and $20 \mathrm{mM},{ }^{18}$ O-labeled water and $50 \mathrm{mM}$ HEPES (4-(2-Hydroxyethyl)-1-piperazineethanesulfonic acid) to buffer the reaction at $\mathrm{pH} 7.4$, and enzyme. This minimal abiotic system permitted measurement of the isotopic effect of PPase without superimposition of other enzymatic or physiological isotopic effects. Solutions comprising buffer, $\mathrm{P}_{\mathrm{i}}$, and $\mathrm{Mg}^{2+}$ were prepared in ${ }^{18} \mathrm{O}$-labeled waters to observe exchange. Experiments were carried out aseptically and maintained under sterile conditions to avoid introduction of phosphoenzymes present in the environment (for example, on skin). First, buffer solutions were filter sterilized $(0.22 \mu \mathrm{M})$, and transferred to sterile reaction tubes/ bottles. Then enzyme preparations that were shipped freeze-dried were dissolved in filter-sterilized ${ }^{18} \mathrm{O}$-labeled water and added to the reaction vessels to initiate reaction. Experiments were conducted at constant temperature in water baths or dry incubators over the range of 5.7 to $30^{\circ} \mathrm{C}$. Enzyme activity was checked periodically over the course of the experiments using standard assay conditions and enzyme manufacturer instructions. PPase remained active throughout the experiments. Five milligrams of dissolved $\mathrm{P}_{\mathrm{i}}$ was extracted periodically from the reaction mixtures using sterile filter-tip pipettes and processed for $\delta^{18} \mathrm{O}_{\mathrm{P}}$ analysis. The extracted solution was added immediately to a 1:1 solution of $\mathrm{NH}_{4} \mathrm{OH}$ to precipitate $\mathrm{MgNH}_{4} \mathrm{PO}_{4}$ and halt any further enzymatic activity and associated isotopic exchange. Next, $\mathrm{MgNH}_{4} \mathrm{PO}_{4}$ was dissolved in $1 \mathrm{M} \mathrm{HNO}$ and recrystallized as $\mathrm{Ag}_{3} \mathrm{PO}_{4}$ for oxygen isotope analysis.

Extracellular phosphate-scavenging enzymes. - Experimental systems with APase comprised $50 \mathrm{mM}$ glycine buffer ( $\mathrm{pH} \mathrm{9),} 37$ to $48 \mathrm{mM}$ of either glucose-1-phosphate, glycerol-2-phosphate or para-nitrophenyl-phosphate (PNPP) phosphomonoester substrate, and APase (Sigma ${ }^{\mathrm{TM}}$ \#3877). Experiments were carried out at 35 to $37^{\circ} \mathrm{C}$ in temperature-controlled water baths. Reaction progress was monitored by periodically extracting $\sim 100$ microliters of the reaction mixture for analysis of dissolved $\mathrm{P}_{\mathrm{i}}$ by the phosphomolybdate blue colorimetric method (Koroleff, 1983). APase activity was monitored over the course of the experiments by performing standard APase assays per enzyme manufacturer instructions (Sigma) on a second small aliquot extracted from the reaction mixture. At the end of the experiments, carried out for several days to weeks, $\mathrm{P}_{\mathrm{i}}$ released from the $\mathrm{P}_{\text {org }}$ substrate was extracted from the medium by precipitation as apatite then converted to silver phosphate for oxygen isotope analysis, following established methods described in Lucas and Prévôt (1984), Hirschler and others (1990) and Blake and others (1997).

Uptake of $P_{i}$ by microbial cells. - Preliminary values of the oxygen isotope fractionation accompanying uptake of $\mathrm{P}_{\mathrm{i}}$ by intact cells were determined in experiments with Escherichia coli (E. coli) grown on a minimal mineral-salts medium (MM1) with $\mathrm{P}_{\mathrm{i}}$ as the sole source of P. MM1 medium (Pfennig and Lippert, 1966) comprised: $\mathrm{NaCl}(5 \mathrm{~g} / \mathrm{L}$ ), $\mathrm{KNO}_{3}(0.5 \mathrm{~g} / \mathrm{L}), \mathrm{MgSO}_{4} \cdot 7 \mathrm{H}_{2} \mathrm{O}(0.2 \mathrm{~g} / \mathrm{L}), \mathrm{NH}_{4} \mathrm{Cl}(0.5 \mathrm{~g} / \mathrm{L})$, and $\mathrm{KH}_{2} \mathrm{PO}_{4}(0.15 \mathrm{~g} / \mathrm{L})$, $\mathrm{CaCl}_{2} \cdot 2 \mathrm{H}_{2} \mathrm{O}(0.1 \mathrm{~g} / \mathrm{L})$, trace elements, $30 \mathrm{mM}$ glycerol and $20 \mathrm{mM}$ MOPS (3- $(\mathrm{N}-$ Morpholino)-propanesulfonic acid) to buffer $\mathrm{pH}$. E. coli cells pre-grown on Luria Broth (LB) broth were washed in carbon-free MM-1 medium then re-suspended in the same medium and used for inoculation. One liter of MM1 experimental $\mathrm{P}_{\mathrm{i}}$-uptake medium was inoculated with approximately 5 to $7 \mathrm{mg}$ of washed $E$. coli biomass. Media were prepared in ${ }^{18} \mathrm{O}$-labeled waters and experiments were carried out in $2 \mathrm{~L}$ bottles (1 $\mathrm{L}$ of medium, $1 \mathrm{~L}$ of gas phase) and incubated at $37^{\circ} \mathrm{C}$. A $50 \mathrm{~mL}$ aliquot of growth 
medium was extracted each day to measure growth as optical density (O.D.) determined as absorption of the culture at $600 \mathrm{nM}$, and $\mathrm{pH}$. $\mathrm{P}_{\mathrm{i}}$ concentration was determined colorimetrically. Media samples were centrifuged and filtered to remove cells and dissolved $\mathrm{P}_{\mathrm{i}}$ was extracted from cell-free filtrate by precipitation of ammonium phosphomolybdate (APM). APM was recrystallized to $\mathrm{MgNH}_{4} \mathrm{PO}_{4}$ and finally to $\mathrm{Ag}_{3} \mathrm{PO}_{4}$ for $\delta^{18} \mathrm{O}_{\mathrm{P}}$ analysis.

Oxygen isotope analyses. - Silver phosphate samples were thoroughly homogenized and loaded into quartz vessels that were then heated to 500 to $550^{\circ} \mathrm{C}$ under vacuum to remove residual water and organic matter. Next, 300 to $400 \mu \mathrm{g}$ of sample were loaded into a pressed silver foil capsule (Costech, $3.5 \times 5 \mathrm{~mm}$ ) and then placed in a Costech Zero-Blank autosampler for reaction, gas chromatographic (GC) separation of gaseous products, and oxygen isotope analysis using a Finnigan Delta ${ }^{\text {plus }} \mathrm{XP}$ with TC/EA (Thermo-Chemical Elemental Analyzer) and Conflo III interface operating in continuous flow mode (YIBS Earth Systems Center for Stable Isotopic Studies). Silver phosphate samples were reacted at $1450^{\circ} \mathrm{C}$ in a graphite reactor crucible to release $\mathrm{O}_{2}$ which, in turn, reacted with the graphite to produce CO (Kornexl and others, 1999). The $\mathrm{CO}$ was entrained in He carrier gas, passed through a GC and introduced into the mass spectrometer. Oxygen isotope ratios were determined by integrating the areas under $\mathrm{CO}$ peaks at masses 28, 29, and 30. All oxygen isotope data are reported as $\delta^{18} \mathrm{O}$ in permil relative to the SMOW international reference standard. Five internal laboratory silver phosphate standards with $\delta^{18} \mathrm{O}_{\mathrm{P}}$ values ranging from -5 to +34 permil were used for data calibration and correction. The precision of the method based on replicate measurement of standards is \pm 0.3 permil. Oxygen isotope ratios of water were determined using the $\mathrm{CO}_{2}$-water equilibration method (Cohn and Urey, 1938).

Recent technical advances in mass spectrometry (Kornexl and others, 1999) and interlaboratory comparison of the three most commonly used methods of $\delta^{18} \mathrm{O}_{\mathrm{P}}$ analysis using a suite of silver phosphate standards optimized for this measurement (Vennemann and others, 2002), have led to revised standardization of some preexisting data. With one exception, discussed below, these revisions do not change the overall trends observed in previous data sets discussed here (table 4; fig. 8; Blake and others, 1997, 1998a, 1998b), but do allow new interpretations in light of the present results.

\section{RESULTS AND DISCUSSION}

\section{Cell-free Enzyme Experiments}

Oxygen isotope effects of PPase: the great equilibrator.-Ten experiments were conducted with PPase in waters whose $\delta^{18} \mathrm{O}$ values ranged widely from -20 to +44 permil in order to detect $\mathrm{P}_{\mathrm{i}}$-water oxygen isotope exchange and to elucidate reaction mechanisms (table 1). The fractionation between $\mathrm{P}_{\mathrm{i}}$ and water approached steady-state values from opposite directions demonstrating equilibrium oxygen isotope exchange catalyzed by PPase (fig. 2). In one experiment, the isotopic composition of water was chosen to be very near equilibrium with $\mathrm{P}_{\mathrm{i}}$ at the start of the experiment such that steady state values were reached early on and remained constant for the duration of the experiment (fig. 2). This approach provided the most accurate determination of fractionation factors at $22^{\circ} \mathrm{C}$. Fractionations determined at $5.7,15$ and $22^{\circ} \mathrm{C}$ are close to equilibrium $\mathrm{P}_{\mathrm{i}}$-water fractionations calculated from the Longinelli and Nuti (1973) equation (table 1). The rapid, equilibrium $\mathrm{P}_{\mathrm{i}}$-water exchange catalyzed by PPase is consistent with the reported reaction mechanism for this enzyme (Cohn, 1953; Janson and others, 1979; Cooperman, 1982): 
TABLE 1

Results from inorganic pyrophosphatase (PPase) experiments

\begin{tabular}{|c|c|c|c|c|c|c|}
\hline Experiment & ID & $\begin{array}{c}\text { Temperature } \\
\left({ }^{\circ} \mathrm{C}\right)\end{array}$ & $\begin{array}{l}\text { Reaction Time } \\
\text { (hours) }\end{array}$ & $\delta^{18} \mathrm{O}_{\mathrm{W}}$ & $\delta^{18} \mathrm{O}_{\mathrm{P}}$ & $10^{3} \ln \alpha$ \\
\hline \multirow[t]{6}{*}{1} & AAS-15 & 15 & 0 & -19.5 & 9.7 & 29.3 \\
\hline & & & 0.58 & & 8.5 & 28.1 \\
\hline & & & 1 & & 8.1 & 27.8 \\
\hline & & & 3 & & 6.3 & 26.0 \\
\hline & & & 30 & & 4.0 & 23.7 \\
\hline & & & 144 & & 4.0 & 23.7 \\
\hline \multirow[t]{6}{*}{2} & AAS-5.7 & 5.7 & 0 & -19.5 & 9.7 & 29.3 \\
\hline & & & 1 & & & \\
\hline & & & 2.5 & & 9.3 & 29.0 \\
\hline & & & 8.5 & & 8.5 & 28.1 \\
\hline & & & 30.5 & & 6.2 & 25.8 \\
\hline & & & 144 & & 6.2 & 25.8 \\
\hline \multirow[t]{4}{*}{3} & $-8.5-22$ & 22 & 0 & -8.5 & 9.7 & 18.2 \\
\hline & & & 26.8 & & 11.8 & 20.2 \\
\hline & & & 71.2 & & & \\
\hline & & & 88 & & 11.8 & 20.2 \\
\hline \multirow[t]{3}{*}{4} & $14-22$ & 22 & 0 & +14.0 & 9.7 & -4.3 \\
\hline & & & 71.2 & & 36.3 & 21.8 \\
\hline & & & 88 & & 36.6 & 22.0 \\
\hline \multirow[t]{5}{*}{5} & AAS-22 & 22 & 0 & -19.4 & 9.7 & 29.2 \\
\hline & & & 0.25 & & 9.3 & 28.9 \\
\hline & & & 1 & & 7.7 & 27.3 \\
\hline & & & 3 & & 5.3 & 24.9 \\
\hline & & & 29.75 & & 2.0 & 21.6 \\
\hline \multirow[t]{5}{*}{6} & $-7.4-5.7$ & 5.7 & 0 & -7.4 & 9.7 & 17.1 \\
\hline & & & 57 & & 16.0 & 23.3 \\
\hline & & & 176 & & 16.9 & 24.2 \\
\hline & & & 393 & & 16.4 & 23.7 \\
\hline & & & 417 & & 16.7 & 24.0 \\
\hline \multirow[t]{2}{*}{7} & $1.4-5.7$ & 5.7 & 0 & +1.4 & 9.7 & 8.2 \\
\hline & & & 54.5 & & 26.5 & 24.7 \\
\hline \multirow[t]{2}{*}{8} & CDSW & var.* & 0 & -17.9 & 15.1 & 33.0 \\
\hline & & & ---- & -17.9 & 5.1 & 23.1 \\
\hline \multirow[t]{2}{*}{9} & $\mathrm{HV}-4$ & var.* & 0 & 1.4 & 15.1 & 13.6 \\
\hline & & & $-\cdots$ & 1.4 & 24.0 & 22.3 \\
\hline 10 & YR3-24 & 24 & 0 & 11.8 & 15.1 & 3.3 \\
\hline
\end{tabular}

*Temperature varied identically for both CDSW and HV-4 


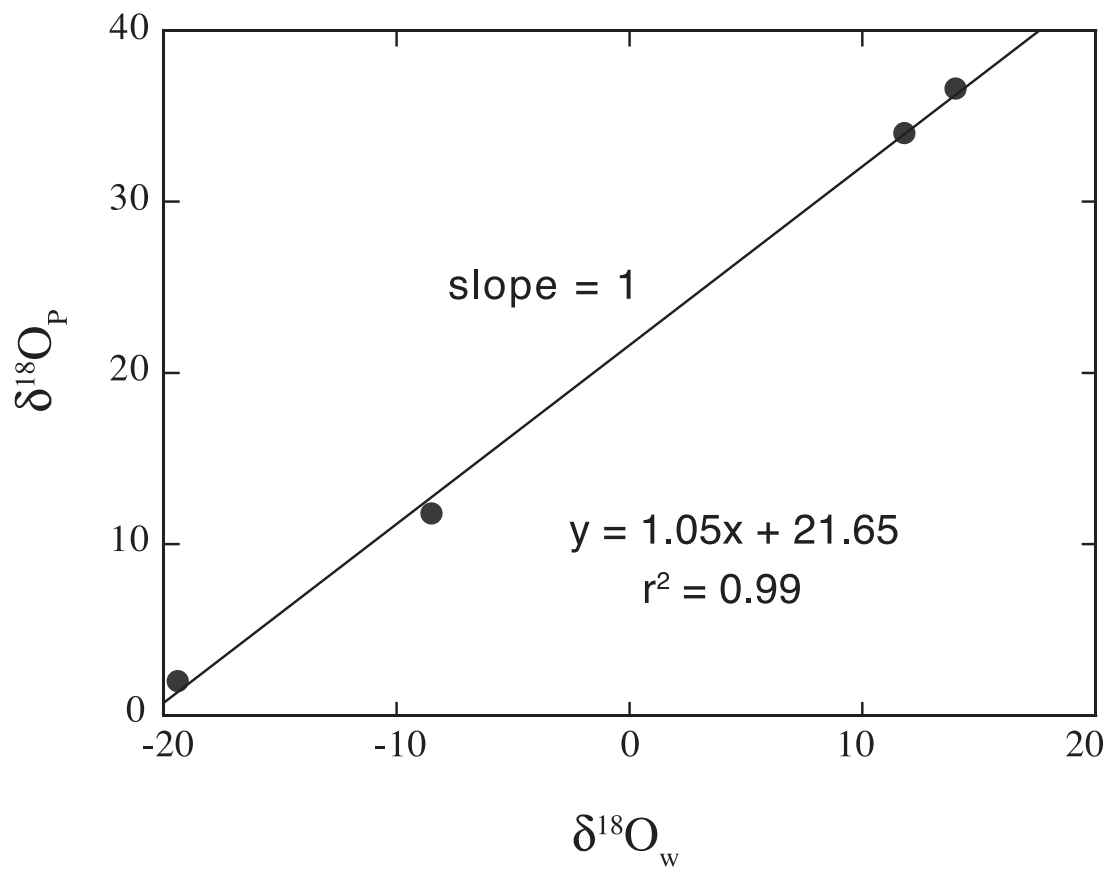

Fig. 3. Results of inorganic pyrophosphatase experiments at $22^{\circ} \mathrm{C} . \delta^{18} \mathrm{O}_{\mathrm{P}}$ plotted against $\delta^{18} \mathrm{O}_{\mathrm{W}}$ shows a strong positive correlation with slope $=1$ indicating extensive exchange between all $\mathrm{O}$ sites in $\mathrm{P}_{\mathrm{i}}$ with water. Compare with 0.3 slope for alkaline phosphatase experiments in figure 6 below.

$$
\underset{\mathrm{PP}_{\mathrm{i}}}{\mathrm{H}_{2} \mathrm{P}_{2} \mathrm{O}_{7}^{2-}+\mathrm{H}_{2} \mathrm{O}} \underset{\text { PPase }}{\stackrel{\mathrm{Mg}^{2+}}{\rightleftarrows}} \underset{\mathrm{HPO}_{4}^{2-}+2 \mathrm{H}^{+}}{\stackrel{\mathrm{P}_{\mathrm{i}}}{\rightleftarrows}}{ }^{\stackrel{2}{2}}
$$

Rapid $\mathrm{P}_{\mathrm{i}}$-water oxygen isotope equilibrium is attained due to extensive oxygen isotope exchange between $\mathrm{P}_{\mathrm{i}}$ and water facilitated by the reversible hydrolysis of $\mathrm{PP}_{\mathrm{i}}$ (eq. 1). A plot of $\delta^{18} \mathrm{O}_{\mathrm{P}}$ against $\delta^{18} \mathrm{O}$ of ambient water has a strong positive correlation $\left(\mathrm{r}^{2}=1\right)$ and a slope of 1 indicating $\mathrm{P}_{\mathrm{i}}$-water exchange at all four oxygen sites in $\mathrm{PO}_{4}$ (fig. 3). Paytan and others (2002) reported complete exchange of $\mathrm{PO}_{4}$-oxygen in algal cells in less than 48 hours. Our results indicate that PPase catalyzes both rapid wholesale exchange of all oxygen sites in $\mathrm{P}_{\mathrm{i}}$ with water, and equilibrium $\mathrm{P}_{\mathrm{i}}$-water fractionations in cell-free systems. We suggest that PPase is also responsible for equilibrium phosphatewater fractionations observed for biogenic apatites.

Temperature-dependence of $P_{i}$-water exchange.-Agreement of the PPase data with empirical measurements of biogenic apatites by Longinelli and Nuti (1973) and verified in several additional studies (Kolodny and others, 1983; Lécuyer and others, 1996), strongly suggests that the ubiquitous PPase is the enzyme responsible for rapid $\mathrm{P}_{\mathrm{i}}$-water exchange, and the equilibrium phosphate-water fractionations observed in $\mathrm{P}_{\mathrm{i}}$-water and biogenic apatite-water systems (fig. 4). In previous experiments with $\mathrm{P}_{\text {org }}$ substrates, no determination was made of $\delta^{18} \mathrm{O}_{\mathrm{P}}$ of $\mathrm{P}_{\mathrm{i}}$ in the medium at different time points or of the unreacted $\mathrm{P}_{\text {org }}$ substrate to assess approach to equilibrium from opposite directions in ${ }^{18} \mathrm{O}$-labeled water. $\mathrm{P}_{\mathrm{i}}$-water fractionations measured at the end of experiments, however, were sufficiently close to equilibrium temperature-dependent fractionations determined from biogenic apatites and described by the Longinelli and 


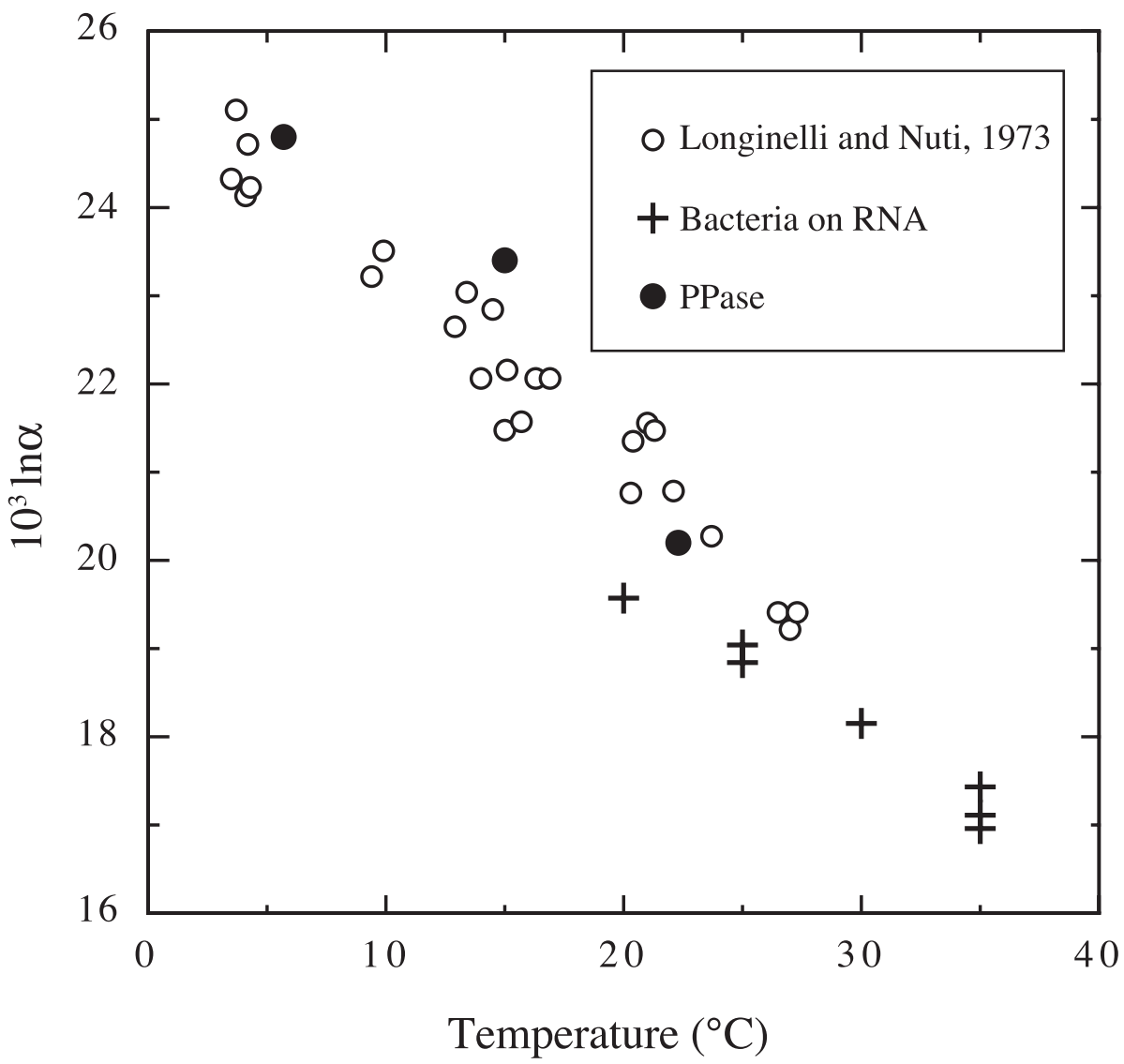

Fig. 4. Temperature-dependence of $\mathrm{P}_{\mathrm{i}}$-water fractionations catalyzed by PPase and intact bacteria cells, compared with the empirical $\mathrm{PO}_{4}$-water relation of Longinelli and Nuti (1973).

Nuti (1973) equation, to suggest that overall equilibrium isotope effects were associated with microbial metabolism of $\mathrm{P}$ (fig. 4).

Enzyme-catalyzed equilibrium oxygen isotope exchange between dissolved sulfate $\left(\mathrm{SO}_{4}\right)$ and water in marine sediments has also been reported (Böttcher and others, 1998, 1999; Blake and others, 2004; Brunner and others, 2005). The specific enzyme(s) and mechanisms responsible for proposed equilibrium $\mathrm{SO}_{4}$-water exchange were recently described by Brunner and others (2005).

Inorganic pyrophosphatase is only one of many intracellular enzymes involved in hydrolysis-condensation reactions of $\mathrm{P}_{\mathrm{i}}$ inside of cells. It is significant, however, that rapid equilibrium exchange can be catalyzed by the action of just one enzyme, further supporting the argument that cumulative enzyme-catalyzed $\mathrm{P}_{\mathrm{i}}$-water exchange reactions lead to equilibrium fractionations observed in biogenic apatites. The present results also suggest that PPase effects may dominate $\delta^{18} \mathrm{O}_{\mathrm{P}}$ signatures by overprinting other isotope effects like that imposed by APase discussed below. It is reasonable to assume that an enzyme or process affecting all four oxygen sites in $\mathrm{PO}_{4}$ would have a dominant effect over processes affecting fewer sites. Nonetheless, the direction and magnitude of fractionations associated with each process will ultimately determine the effect on $\delta^{18} \mathrm{O}_{\mathrm{P}}$. For example, large fractionations may be of opposite sign thus 
TABLE 2

Results from experiments with APase

\begin{tabular}{lcc}
\hline Substrate & $\delta^{18} \mathrm{O}_{\mathrm{P}}$ & $\delta^{18} \mathrm{O}_{\mathrm{W}}$ \\
\hline p-nitrophenol phosphate & -4.4 & -19.0 \\
Glucose-1-PO & 1.2 & -19.0 \\
Glycerol-2- $-\mathrm{PO}_{4}$ & -6.9 & -19.0 \\
Glycerol-2- $\mathrm{PO}_{4}$ & -6.1 & -19.0 \\
Glycerol-2- $\mathrm{PO}_{4}$ & 13.0 & 44.0 \\
\hline
\end{tabular}

canceling each other out; or the fractionation associated with a process affecting all oxygen sites in $\mathrm{PO}_{4}$ may be smaller than that of a process affecting only one or two sites. These multiple and potentially complex scenarios point further to the importance of direct characterization of specific isolated processes like the single enzyme effects reported here, combined with measurements of $\delta^{18} \mathrm{O}_{\mathrm{P}}$ in natural systems covering a wide range of conditions.

Non-equilibrium isotope effects of Apase.-Five experiments were conducted with APase to examine the oxygen isotope effects of this enzyme on three different phosphomonoester substrates: para-nitrophenol- $\mathrm{PO}_{4}$, glucose-1- $\mathrm{PO}_{4}$ and glycerol-2$\mathrm{PO}_{4}$ (table 2). $\delta^{18} \mathrm{O}_{\mathrm{P}}$ values of $\mathrm{P}_{\mathrm{i}}$ released from the three different phosphomonoesters in water with the same $\delta^{18} \mathrm{O}$ value $(-19$ permil) differ by 2.5 to 8.5 permil. All things being equal except the substrate, and assuming that the APase isotope effect is the same for each substrate, the $\delta^{18} \mathrm{O}_{\mathrm{P}}$ values of released $\mathrm{P}_{\mathrm{i}}$ must include contributions from another oxygen pool with a different $\delta^{18} \mathrm{O}$ value. This additional oxygen is most likely contributed by the original $\mathrm{P}_{\text {org }}$ substrate. The well known APase reaction mechanism is consistent with this interpretation (fig. 5).

Inheritance of oxygen.-Blake and others (1997) concluded that $\mathrm{P}_{\mathrm{i}}$ released during microbial metabolism of RNA, a phosphodiester, inherits 50 percent of its oxygen from the RNA substrate. Release of $P_{i}$ from RNA requires the action of two different enzymes. First, RNAse or phosphodiesterase catalyzes an intramolecular reaction that converts the phosphodiester structure into phosphomonoesters (fig. 5A). Next the phosphomonoesters are hydrolyzed by APase to release free $\mathrm{P}_{\mathrm{i}}$ to the medium (fig. 5B). A model was constructed based on the two-step RNA enzymatic degradation mechanism (fig. 5B) that assumes incorporation of oxygen from water at two of the four sites in $\mathrm{P}_{\mathrm{i}}$ in equilibrium with $\mathrm{P}_{\mathrm{i}}$ (Blake and others, 1997). Whether water was incorporated into released $\mathrm{P}_{\mathrm{i}}$ directly with no fractionation, or with equilibrium or kinetic fractionations however, could not be evaluated from those experiments. Cell-free APase experiments presented here, shed new light on this question.

Glycerol-2-phosphate was used in experiments with APase in waters with different $\delta^{18} \mathrm{O}$ values $(-19$ and +44 permil $)$ to explore further the extent of $\mathrm{P}_{\mathrm{i}}$-water oxygen isotope exchange during hydrolysis. Figure 6 is a plot of $\delta^{18} \mathrm{O}_{\mathrm{P}}$ of inorganic $\mathrm{PO}_{4}$ released by APase hydrolysis of glycerol-2-phosphate versus the $\delta^{18} \mathrm{O}$ value of water. The positive correlation between $\delta{ }^{18} \mathrm{O}_{\mathrm{W}}$ and $\delta^{18} \mathrm{O}_{\mathrm{P}}$ indicates that water is incorporated into $\mathrm{PO}_{4}$ during APase hydrolysis. A simple mixing model that assumes approximately 25 percent incorporation of water into $\mathrm{PO}_{4}$ is consistent with observed data and the APase reaction mechanism. Thus, most $(\sim 75 \%)$ of the oxygen in $\mathrm{PO}_{4}$ released during glycerol-2-phosphate hydrolysis by APase is inherited from the original $\mathrm{P}_{\text {org }}$ substrate. Recent experimental studies of the precise nature of incorporation of water into $\mathrm{PO}_{4}$ during APase-catalyzed hydrolysis of phosphomonoesters such as glycerol-2-phosphate 


\section{A. Ribonuclease mechanism}

RNA structure

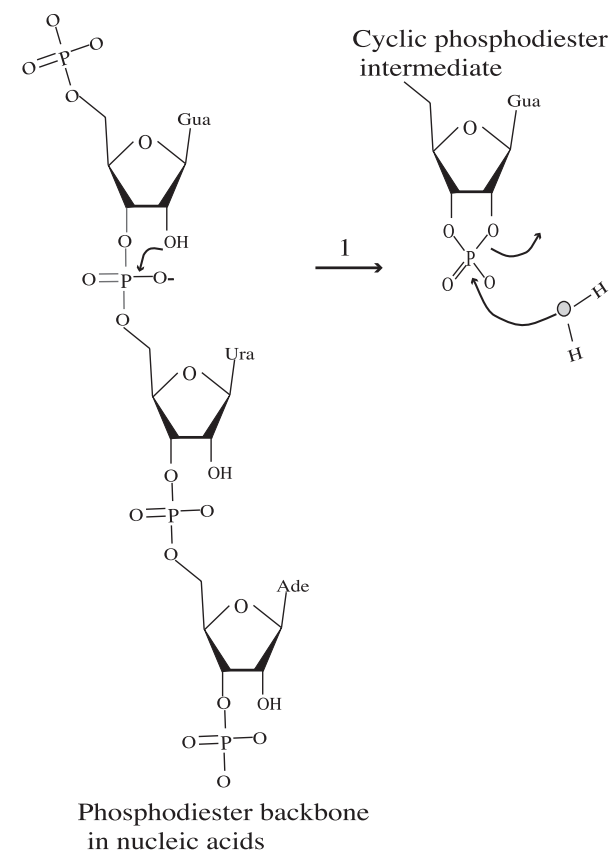

B. Alkaline phosphatase mechanism

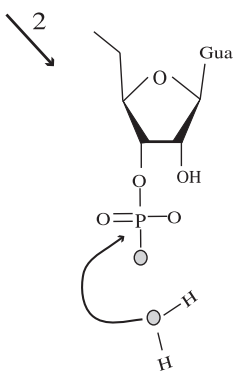

3'-phosphate nucleotide phosphomonoester

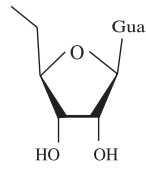

C-org

$+$

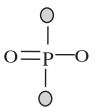

free $\mathrm{Pi}$

Fig. 5. RNAse and APase mechanims for release of free Pi from RNA modified from Walsh (1979). (A) Ribonuclease catalyzes the initial enzymatic hydrolysis of RNA in 2 steps: Step 1 is an intramolecular rearrangement with attack by 2 '-OH on internucleotide $\mathrm{PO}_{4}$ groups in the RNA backbone; Step 2 involves hydrolytic attack on the cyclic phosphodiester produced in Step 1 to give a phosphomonoester with $1 \mathrm{O}$ atom derived from ambient water. (B) Alkaline phosphatase (APase) catalyzes Step 3, the final step in RNA hydrolysis which releases free $\mathrm{P}_{\mathrm{i}}$. A second hydrolytic attack on $\mathrm{P}$ in the phosphomonoester produced in Step 2 is catalyzed by APase and results in incorporation of a second water $\mathrm{O}$ atom into $\mathrm{P}_{\mathrm{i}}$ derived from RNA hydrolysis.

by Liang (Liang and Blake, 2002; Liang, ms, 2005), indicate that incorporation of water-oxygen is accompanied by a large kinetic isotope effect on the order of -30 permil.

Release of $\mathrm{P}_{\mathrm{i}}$ during degradation of dead biomass-again mediated by phosphohydrolase enzymes like APase-is expected to produce $\mathrm{P}_{\mathrm{i}}$ with disequilibrium isotope effects like those described above. Whether the isotopic imprint of $\mathrm{P}_{\mathrm{i}}$-regeneration or that of $\mathrm{P}_{\mathrm{i}}$ turvover/cycling is retained in $\mathrm{P}_{\mathrm{i}}$, and which of these isotopic effects dominates the $\delta^{18} \mathrm{O}_{\mathrm{P}}$ signature, can be best assessed by studies of more complex and chemically evolved culture systems, including natural environments.

\section{Microbial Culture Experiments}

Fractionation during uptake of $P_{i}$ by intact cells.-Results of preliminary experiments on oxygen isotope fractionation accompanying uptake of $\mathrm{P}_{\mathrm{i}}$ by intact cells of $E$. coli are presented in table 3 and plotted in figure $7 . \delta^{18} \mathrm{O}_{\mathrm{P}}$ of the growth medium increased by as much as 2 permil during the period of maximum $\mathrm{P}_{\mathrm{i}}$ uptake which also coincided with the maximum rate of growth (fig. 7). Phosphate containing the light isotope of oxygen was taken up preferentially by cells during exponential growth ( $\sim 90$ to 250 hrs) causing the $\delta^{18} \mathrm{O}_{\mathrm{P}}$ value of the growth medium to increase from 13.5 to 15.6 
610 R. E. Blake, J. R. O’Neil, and A. V. Surkov-Biogeochemical cycling of phosphorus:

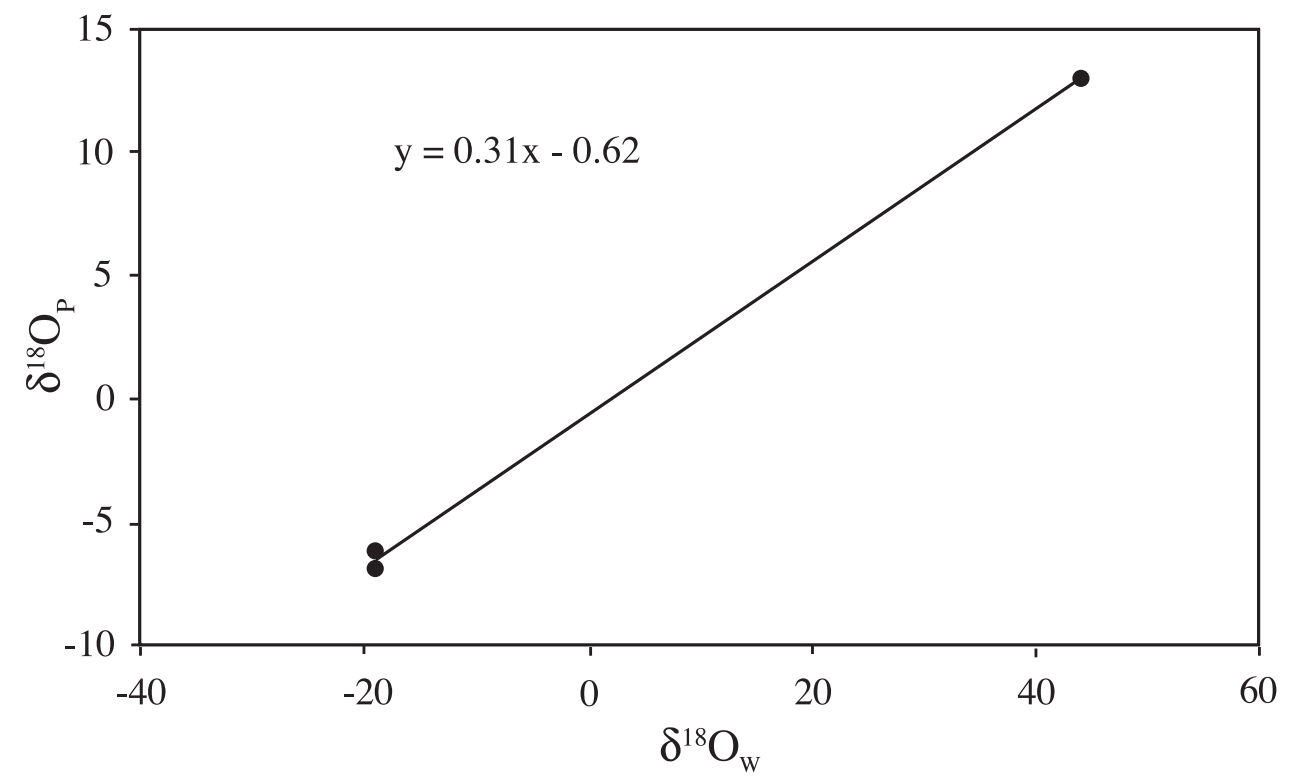

Fig. 6. Results of 3 APase experiments in ${ }^{18} \mathrm{O}$-labeled water at $37^{\circ} \mathrm{C} . \delta^{18} \mathrm{O}_{\mathrm{P}}$ of $\mathrm{P}_{\mathrm{i}}$ released from glycerol-2-phosphate by APase versus $\delta^{18} \mathrm{O}_{\mathrm{W}}$. Positive correlation between $\delta^{18} \mathrm{O}_{\mathrm{P}}$ and $\delta^{18} \mathrm{O}_{\mathrm{W}}$ indicates incorporation of water into $\mathrm{P}_{\mathrm{i}}$ released by hydrolysis of glycerol-2-phosphate by APase.

TABLE 3

Results from E. coli $P_{i}$ uptake experiments at $37^{\circ} \mathrm{C}$

\begin{tabular}{ccccc}
\hline $\begin{array}{c}\text { Growth time } \\
\text { (hours) }\end{array}$ & $\begin{array}{c}\text { O.D. 600 } \\
(\mathrm{nM})\end{array}$ & $\begin{array}{c}\mathrm{Pi} \\
(\mu \mathrm{M})\end{array}$ & $\delta^{18} \mathrm{O}_{\mathrm{P}}$ & $\mathrm{pH}$ \\
\hline 0 & 0.0043 & 943 & 14.8 & 7.1 \\
17 & 0.007 & $\cdots-$ & $\cdots$ & $\cdots$ \\
24 & 0.0082 & $\ldots .-$ & $\ldots \ldots .-$ & $\cdots$ \\
50 & 0.042 & 1074 & 13.9 & 7 \\
89 & 0.126 & 1033 & 13.5 & 6.8 \\
112 & 0.125 & 1046 & 13.7 & 6.8 \\
136 & 0.135 & 793 & 13.7 & 6.5 \\
160 & 0.147 & 827 & 14.1 & 6.5 \\
184 & 0.259 & 761 & 14.7 & 6.4 \\
256 & 0.574 & 577 & 15.6 & 6.4 \\
283 & 0.602 & 964 & 15.2 & 6.3 \\
307 & 0.615 & 918 & 15.0 & 6.1 \\
385 & 0.825 & 861 & 14.9 & 6.1 \\
427 & 0.866 & 849 & 15.1 & 6.5 \\
449 & 0.877 & ---- & --- & --- \\
497 & 0.894 & 896 & --- & 6.7 \\
593 & 0.845 & 933 & 15.2 & 7.1 \\
\hline
\end{tabular}

-not determined 

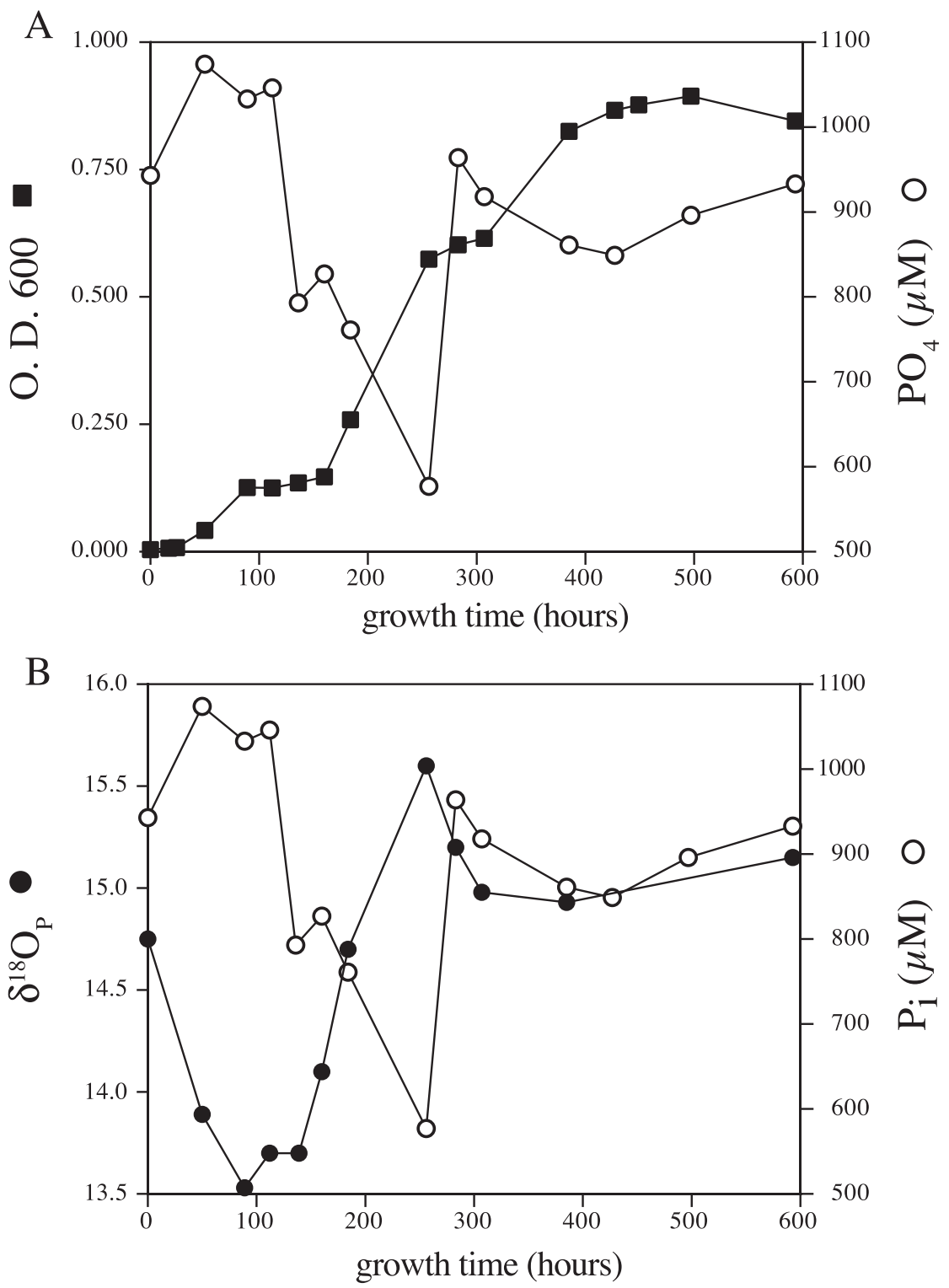

Fig. 7. Results of experiments on $\mathrm{P}_{\mathrm{i}}$ uptake by intact E. coli cells grown on inorganic phosphate $\left(\mathrm{P}_{\mathrm{i}}\right)$ minimal medium at $37^{\circ} \mathrm{C}$. The growth curve for $E$. coli plotted against $\mathrm{P}_{\mathrm{i}}$ concentration in the growth medium (A) shows that approximately 40 percent of the $\mathrm{P}_{\mathrm{i}}$ pool is taken up by cells by the mid-exponential phase of growth ( $\sim 270$ hours). Growth is expressed as optical density (O.D.) measured spectrophotometrically at $600 \mathrm{~nm}$ which is a proxy for cell number. The $\delta^{18} \mathrm{O}_{\mathrm{P}}$ of residual $\mathrm{P}_{\mathrm{i}}$ in the medium increases by a maximum of 2 permil during the period of maximum $\mathrm{P}_{\mathrm{i}}$ uptake by E. coli (between about 50 and 270 hours) (B). Subsequent release of $\mathrm{P}_{\mathrm{i}}$ from cells (increase in $\mathrm{P}_{\mathrm{i}}$ in the medium) was observed between 270 and 300 hours with a concomitant decrease in $\delta^{18} \mathrm{O}_{\mathrm{P}}$ of $\mathrm{P}_{\mathrm{i}}$ by about 0.5 permil.

permil coupled with a decrease in $\mathrm{P}_{\mathrm{i}}$ concentration from 1074 to $577 \mu \mathrm{M}$. This process represented uptake of $\sim 45$ percent of the $\mathrm{P}_{\mathrm{i}}$ pool (fig. 7B). The initial increase in concentration of $\mathrm{P}_{\mathrm{i}}$ in the medium and associated decrease in $\delta^{18} \mathrm{O}_{\mathrm{P}}$ from a starting value of 14.8 to a minimum of 13.5 permil ( 0 to about $80 \mathrm{hrs}$ ) may be explained by 
excretion of $\mathrm{P}_{\mathrm{i}}$ that was previously stored inside of cells under conditions of $\mathrm{P}_{\mathrm{i}}$ excess and so-called luxury $\mathrm{PO}_{4}$ uptake in the LB broth medium (Hellweger and others, 2003).

Alternatively, this initial negative shift in $\delta^{18} \mathrm{O}_{\mathrm{P}}$ may be caused by cycling or turnover of $\mathrm{P}$ by cells with intracellular $\mathrm{P}_{\mathrm{i}}$-water exchange and resetting of $\delta^{18} \mathrm{O}_{\mathrm{P}}$. Using the equation of Longinelli and Nuti (1973), the estimated equilibrium value of $\delta^{18} \mathrm{O}_{\mathrm{P}}$ is around 11 permil under the conditions of the experiments $\left(\mathrm{T}=37^{\circ} \mathrm{C}\right.$ and $\delta^{18} \mathrm{O}_{\mathrm{W}}=-6$ permil). Excretion of $\mathrm{P}_{\mathrm{i}}$ into the growth medium with a $\delta^{18} \mathrm{O}_{\mathrm{P}}$ of 11 permil would shift the overall $\delta{ }^{18} \mathrm{O}_{\mathrm{P}}$ value of the $\mathrm{P}_{\mathrm{i}}$ pool toward more negative values, as observed. More detailed experiments are currently underway to test these hypotheses. Nevertheless, during the period of maximum uptake of $\mathrm{P}_{\mathrm{i}}$ by cells between 90 to $250 \mathrm{hrs}$, there is clear preferential uptake of $\mathrm{P}^{16} \mathrm{O}_{4}$. Thus, $\mathrm{P}_{\mathrm{i}}$ appears to adhere to the behavior observed for other isotopic species in diffusion controlled and enzyme-mediated processes, such as preferential uptake of ${ }^{12} \mathrm{C}$ and ${ }^{16} \mathrm{O}$ in $\mathrm{CO}_{2}$ during photosynthesis or ${ }^{32} \mathrm{~S}$ and ${ }^{16} \mathrm{O}$ in $\mathrm{SO}_{4}$ during microbial sulfate reduction. Fractionations during $\mathrm{P}_{\mathrm{i}}$ uptake and excretion in natural systems may be larger or smaller and will depend on the total concentration of $\mathrm{P}_{\mathrm{i}}$, percentage of $\mathrm{P}_{\mathrm{i}}$ taken up from the medium, and effects introduced from other isotopic fractionations that may completely overprint the uptake signature.

The $\mathrm{PO}_{4}$-water oxygen isotope fractionation factor can be estimated by assuming a closed system and using a simplified Rayleigh equation (for example, Rayleigh, 1896; Mitzutani and Rafter, 1973; Goldhaber and Kaplan, 1974; Aharon and Fu, 2000) to model the data:

$$
\Delta \delta^{18} \mathrm{O}_{\mathrm{P}}=\delta_{\mathrm{t}}-\delta_{0}=10^{3}(\alpha-1) \operatorname{lnf}
$$

where $\delta_{t}=\delta^{18} \mathrm{O}$ of residual $\mathrm{P}_{\mathrm{i}}$ at time $\mathrm{t} ; \delta_{0}=$ initial $\delta^{18} \mathrm{O}$ of $\mathrm{P}_{\mathrm{i}}$; and $\mathrm{f}=$ fraction of $\mathrm{P}_{\mathrm{i}}$ remaining at time t. $\mathrm{f}=1$ at $\mathrm{t}=0$. The apparent fractionation is obtained from the slope of this equation, $10^{3}(\alpha-1)$, expressed in permil. The fractionation due to uptake of $\mathrm{P}_{\mathrm{i}}$ by E. coli is -3.2 permil (fig. 8), which is close to the value of -3 per mil determined for the fractionation of $\mathrm{S}$ accompanying uptake of $\mathrm{SO}_{4}$ in dissimilatory sulfate reduction by Desulfovibrio desulfuricans (Rees, 1973). During bacterial sulfate reduction, oxygen in $\mathrm{SO}_{4}$ undergoes kinetic fractionation similar to sulfur, but of lower magnitude (Mitzutani and Rafter, 1973; Fritz and others, 1989).

Comparison with previous laboratory studies.-Results of the present experiments on PPase and APase isotope effects provide plausible explanations for observations made in previous experimental studies by Blake and others (1997, 1998a, 1998b) and Paytan and others (2002). A plot comparing microbial cultures grown on $\mathrm{P}_{\text {org }}$ compounds with cell-free enzyme experiments (fig. 9) shows that $\mathrm{P}_{\mathrm{i}}$ in the microbial cultures lies between two end-member boundaries defined by PPase (complete $\mathrm{P}_{\mathrm{i}}$-water exchange) and APase (exchange at only 1 of four oxygen sites in $\mathrm{P}_{\mathrm{i}}$ ). This finding supports previous conclusions that $\delta^{18} \mathrm{O}_{\mathrm{P}}$ of $\mathrm{P}_{\mathrm{i}}$ in the microbial culture systems reflected enzymatic hydrolysis followed by only partial uptake and turnover of the $\mathrm{P}_{\mathrm{i}}$ pool. High total $\mathrm{P}_{\mathrm{i}}$ and $\mathrm{P}_{\text {org }}$ concentrations imposed by analytical constraints at the time of previous experiments resulted in incomplete turnover/metabolism of the released $\mathrm{P}_{\mathrm{i}}$ in most cases. Thus, it was hypothesized that some oxygen from the initial unreacted $\mathrm{P}$ source contributed to the final measured $\delta^{18} \mathrm{O}_{\mathrm{P}}$ values of $\mathrm{P}_{\mathrm{i}}$. It was further hypothesized that in the case of $\mathrm{P}_{\text {org }}$ substrates, some oxygen in $\mathrm{P}_{\mathrm{i}}$ released to the medium by extracellular enzymatic hydrolysis was inherited from $\mathrm{P}_{\text {org }}$ (Blake and others, 1997, 1998a).

These inheritance and partial turnover isotope effects would result in slopes of less than 1 in $\delta^{18} \mathrm{O}_{\mathrm{P}^{-}-} \delta^{18} \mathrm{O}_{\mathrm{W}}$ space and a shift in $\delta^{18} \mathrm{O}_{\mathrm{P}}$ from the equilibrium line (figs. 4 and 9). Because most marine and freshwater systems have low $P_{i}$ concentrations of $<<0.5$ to $1 \mu \mathrm{M}$, over an order of magnitude below the lowest $\mathrm{P}_{\mathrm{i}}$ concentration used in their experiments, Blake and others $(1997,1998 \mathrm{a}, 2001)$ suggested that dissolved $P_{i}$ in 


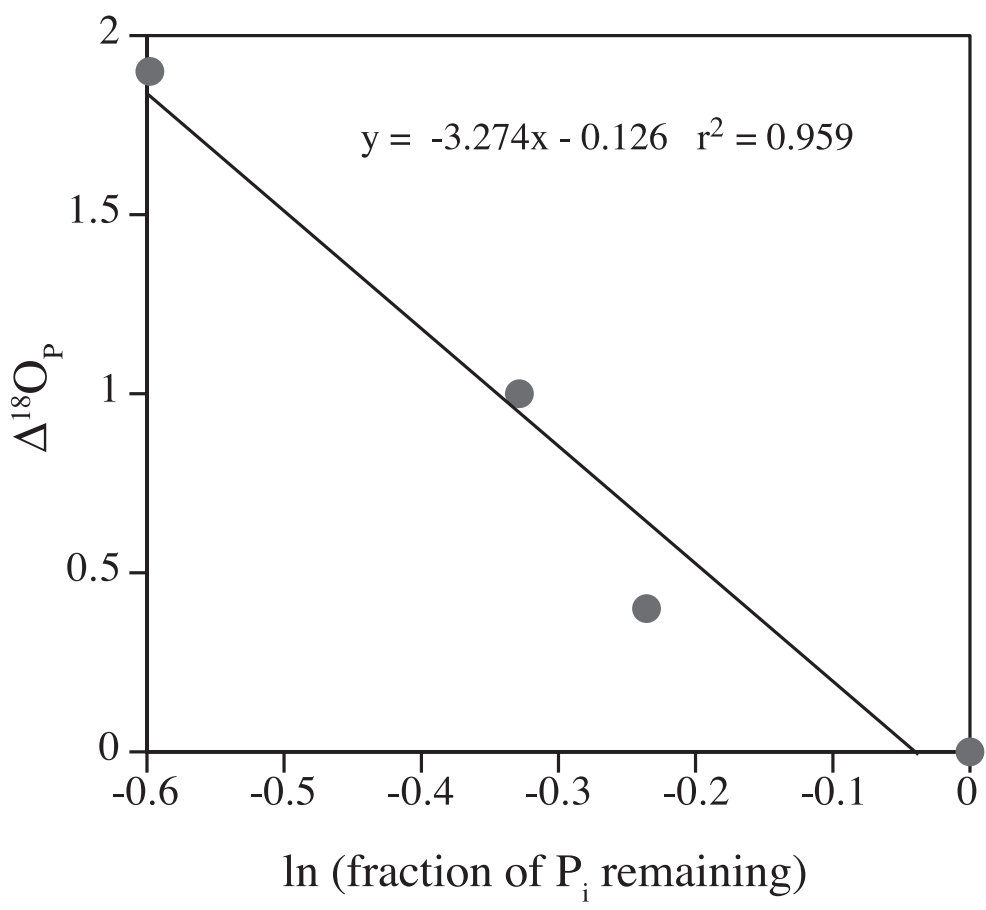

Fig. 8. Rayleigh plot for $\mathrm{P}_{\mathrm{i}}$ uptake by E. coli at $37^{\circ} \mathrm{C}$. The slope indicates a permil fractionation of -3.3 permil for this process. $\Delta \delta^{18} \mathrm{O}_{\mathrm{P}}$ is defined in equation 2.

most natural waters should be at or near isotopic equilibrium with ambient water because of the intense recycling of $\mathrm{P}$ expected in such low- $\mathrm{P}_{\mathrm{i}}$ systems. Under such conditions a slope of about 1 in $\delta^{18} \mathrm{O}_{\mathrm{P}}-\delta^{18} \mathrm{O}_{\mathrm{W}}$ space is expected.

Uptake and turnover of $P_{i}$ by cells. - Rapid $\mathrm{P}_{\mathrm{i}}$-water exchange was observed in 1988 mesocosm field experiments described by Paytan and others (2002). These researchers added ${ }^{18} \mathrm{O}$-labeled $\mathrm{P}_{\mathrm{i}}$ to marine algal cultures and observed that $\delta^{18} \mathrm{O}_{\mathrm{P}}$ values of extracellular $\mathrm{P}_{\mathrm{i}}$ approached original values as phosphate was rapidly cycled by growing cells. Although measured $\delta^{18} \mathrm{O}_{\mathrm{P}}$ values reported by Paytan and others did not reflect $\mathrm{P}_{\mathrm{i}}$-water equilibrium, the rapid and extensive $\mathrm{P}_{\mathrm{i}}$-water exchange observed in their experiments is consistent with the rapid $\mathrm{P}_{\mathrm{i}}$-water exchange catalyzed by PPase. $\mathrm{P}_{\text {org }}$ substrates were not added to the algal cultures, so APase isotope effects are not expected. A kinetic fractionation due to uptake of $\mathrm{P}_{\mathrm{i}}$ by cells was not indicated in the results of the Paytan and others (2002) mesocosm experiments. Previous laboratory culture experiments on microbial metabolism of $\mathrm{P}_{\mathrm{i}}$ by Blake and others (1998a) do indicate that such effects are in play.

Revised standardization of the data presented in Blake and others (1998a) according to methods of Vennemann and others (2002) permit new interpretations. Results of experiments with Klebsiella aerogenes grown under conditions of high (10 $\mathrm{mM}) \mathrm{P}_{\mathrm{i}}$ and incomplete uptake of extracellular phosphate (table 4) indicate two superimposed isotope effects on the $\mathrm{P}_{\mathrm{i}}$ pool: (1) preferential uptake of the lighter isotopic species $\mathrm{P}^{16} \mathrm{O}_{4}$, and (2) rapid equilibrium $\mathrm{P}_{\mathrm{i}}$-water exchange. The overall equilibrium isotope fractionation between phosphate and water in the growth medium is clearly demonstrated by the approach to steady-state $\mathrm{P}_{\mathrm{i}}$-water fractionation from opposite directions with increasing $\mathrm{P}_{\mathrm{i}}$ turnover by $K$. aerogenes (fig. 10). Previously 


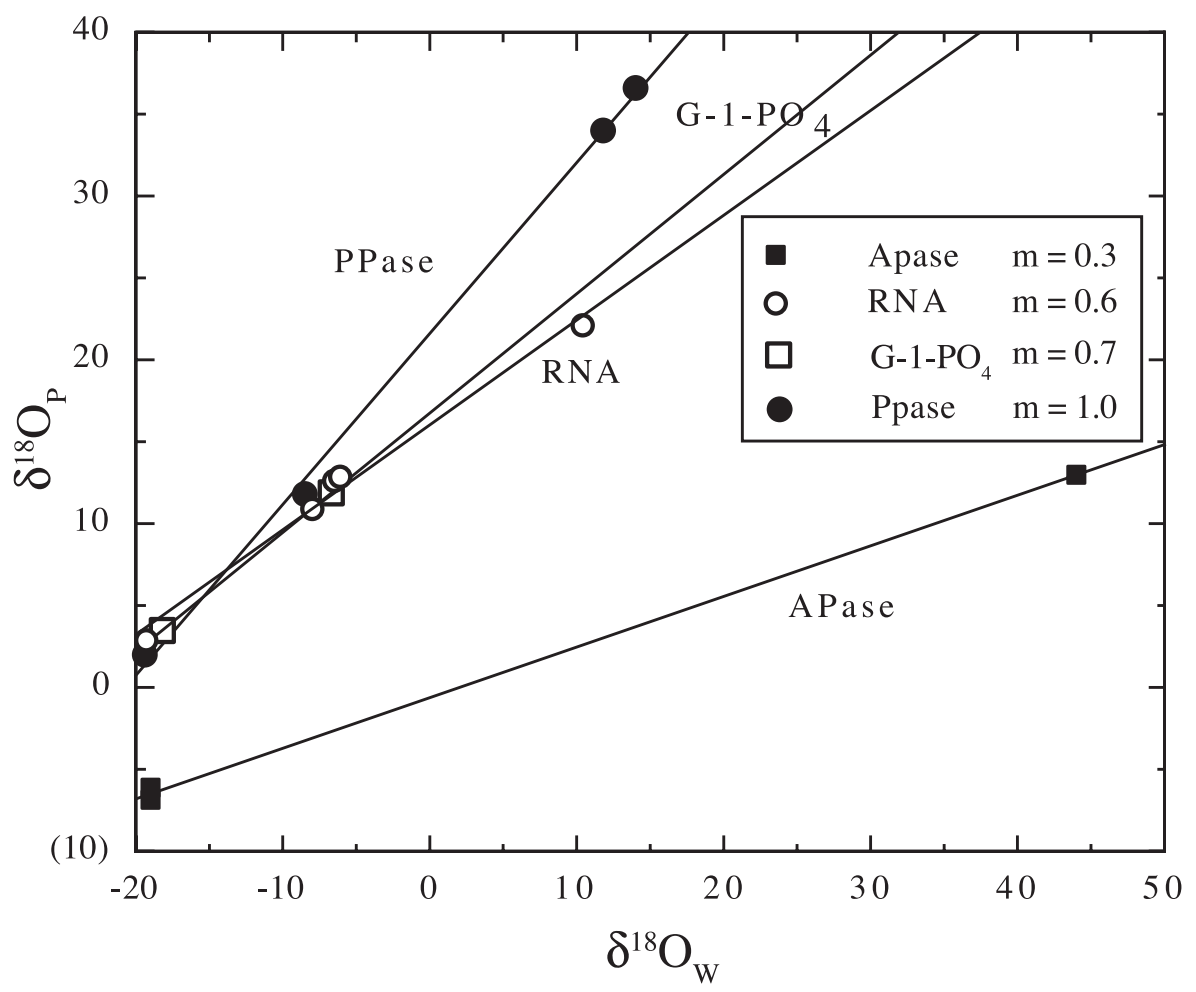

Fig. 9. Comparison of slopes from all experiments in $\delta^{18} \mathrm{O}_{\mathrm{P}}-\delta^{18} \mathrm{O}_{\mathrm{W}}$ space. Inheritance and partial turnover/exchange of $\mathrm{P}_{\mathrm{i}}$ result in slopes of less than 1. Microbial cultures grown on glucose-1-phosphate $\left(\mathrm{G}-1-\mathrm{PO}_{4}\right)$ and RNA give slopes that lie between two end-member boundaries defined by PPase (complete $\mathrm{P}_{\mathrm{i}}$-water exchange) and APase (partial $\mathrm{P}_{\mathrm{i}}$-water exchange with inheritance of $\mathrm{O}$ from $\mathrm{P}_{\text {org }}$ in 3 of 4 oxygen sites in $\mathrm{PO}_{4}$.

published $\delta^{18} \mathrm{O}_{\mathrm{P}}$ values (table 4 ) indicated widely ranging $\mathrm{P}_{\mathrm{i}}$-water fractionations at the end of experiments. Revised $\delta^{18} \mathrm{O}_{\mathrm{P}}$ values, however, show that the same steady-state fractionation of 24 permil was reached using all three labeled waters, that is, coming from different directions and distances (table 4; fig. 10). The $\sim 4$ permil positive offset in $\delta^{18} \mathrm{O}$ values of residual extracellular $\mathrm{P}_{\mathrm{i}}$ from the calculated equilibrium fractionation at $25^{\circ} \mathrm{C}\left(\sim 20\right.$ permil) reflects the preferential uptake of $\mathrm{P}^{16} \mathrm{O}_{4}$ from the $\mathrm{P}_{\mathrm{i}}$ pool. Thus, equilibrium isotope effects are partially overprinted by a kinetic fractionation that involves preferential uptake of $\mathrm{P}^{16} \mathrm{O}_{4}$ and shift to higher $\delta^{18} \mathrm{O}_{\mathrm{P}}$ values for residual phosphate. These results demonstrate that biota can produce both kinetic and equilibrium phosphate oxygen isotope effects that can be reflected in $\delta^{18} \mathrm{O}_{\mathrm{P}}$ values at high phosphate concentrations in laboratory systems. Dominance of equilibrium, kinetic, or inheritance (disequilibrium) isotope effects in natural systems will depend on growth conditions and the concentrations and sources of $\mathrm{P}\left(\mathrm{P}_{\mathrm{i}}\right.$ or $\left.\mathrm{P}_{\text {org }}\right)$ in the environment. Hudson and others $(2000)$ observed very short $(<10 \mathrm{~min})$ turnover times for $\mathrm{P}_{\mathrm{i}}$ in microbial populations of freshwater lakes at very low ambient $\mathrm{P}$ concentrations, indicating a very high flux of phosphate through the system to maintain observed rates of growth (Karl, 2000). Similarly, Benitez-Nelson and Buesseler (1999) reported rapid (days to weeks) turnover times for $\mathrm{P}_{\mathrm{i}}$ and a significant fraction of $\mathrm{P}_{\text {org }}$ in the Gulf of Maine on the basis of measurements of the cosmogenic radioisotopes, ${ }^{32} \mathrm{P}$ and ${ }^{33} \mathrm{P}$. It should be noted, that under such conditions of low $\mathrm{P}_{\mathrm{i}}$ 
TABLE 4

Corrected $\delta^{18} O_{p}$ values for DIP in growth media from previous microbial culture experiments in ${ }^{18}$ O-labeled waters. (Corrected according to Vennemann and others, 2002)

\begin{tabular}{|c|c|c|c|c|c|}
\hline P Source & Temperature $\left({ }^{\circ} \mathrm{C}\right)$ & $\delta^{18} \mathrm{O}_{\mathrm{W}}$ & $\delta^{18} \mathrm{O}_{\mathrm{P}}$ & $\begin{array}{c}\delta^{18} \mathrm{O}_{\mathrm{p}}- \\
\text { Corrected }\end{array}$ & $10^{3} \ln \alpha$ \\
\hline Phosphodiester $^{1}$ & 15 & -19.5 & 7.2 & 4.3 & 24 \\
\hline \multirow[t]{10}{*}{ RNA } & 20 & -6.3 & 14.6 & 13.4 & 19.6 \\
\hline & 25 & -19.3 & 6 & 2.9 & 22.2 \\
\hline & $"$ & -8.0 & 12.6 & 10.9 & 18.9 \\
\hline & $"$ & -6.5 & 14 & 12.6 & 19.1 \\
\hline & $"$ & -6.1 & 14.2 & 12.8 & 18.9 \\
\hline & $"$ & 10.4 & 21.8 & 22.1 & 11.7 \\
\hline & 30 & -6.2 & 13.5 & 12.0 & 18.2 \\
\hline & 35 & -6.2 & 12.9 & 11.3 & 17.4 \\
\hline & 35 & -6.6 & 12.3 & 10.5 & 17.1 \\
\hline & 35 & -5.5 & 13.1 & 11.5 & 17.0 \\
\hline Phosphomonoester $^{2}$ & 25 & -18.2 & 6.5 & 3.5 & ---- \\
\hline Glucose-1phosphate & $"$ & -6.7 & 13.4 & 11.9 & ---- \\
\hline Inorganic $\mathrm{Pi}^{1}$ & 25 & -17.7 & 9.3 & 6.7 & 24.4 \\
\hline \multirow[t]{2}{*}{$10 \mathrm{mM} \mathrm{Pi}$} & & -6.0 & 18.6 & 18.2 & 24.2 \\
\hline & & 12.6 & 33.9 & 36.8 & 24.2 \\
\hline
\end{tabular}

1. Data from Blake and others, 1997.

2. Data from Blake and others, 1998a.

concentration and intense recycling of $\mathrm{P}_{\mathrm{i}}$ by cells, uptake and turnover of the entire $\mathrm{P}_{\mathrm{i}}$ pool is expected to result in complete $\mathrm{P}_{\mathrm{i}}$-water oxygen isotope exchange and dominance of equilibrium isotope effects in $\mathrm{P}_{\mathrm{i}}$. Attainment of these equilibrium isotope effects is catalyzed primarily by PPase.

\section{Applications of $\delta^{18} O_{P}$ to Studies of Biogeochemical P Cycling}

$\delta^{18} O_{P}$ as a dynamic and conservative tracer of $P$ cycling.- Under most environmental conditions, $\delta^{18} \mathrm{O}_{\mathrm{P}}$ does not serve as a completely conservative tracer of $\mathrm{P}_{\mathrm{i}}$ or $\mathrm{P}_{\text {org }}$ sources, but rather as a dynamic tracer of $\mathrm{P}_{\mathrm{i}}$ cycling. Dynamic tracer properties of $\delta^{18} \mathrm{O}_{\mathrm{P}}^{\text {org }}$ result from the action of PPase and other enzymes, which catalyze rapid and extensive oxygen isotope exchange between $\mathrm{P}_{\mathrm{i}}$ and water. Paytan and others (2002) demonstrated the dynamic tracer property of $\delta^{18} \mathrm{O}_{\mathrm{P}}$, which allowed estimates to be made of $\mathrm{P}$ turnover rates in their aquaculture systems. The strong temperature dependence of equilibrium $\mathrm{P}_{\mathrm{i}}$-water exchange observed in our experiments may also provide a method for following $\mathrm{P}_{\mathrm{i}}$ cycling reflected in $\delta^{18} \mathrm{O}_{\mathrm{P}}$. Importantly, this property expands the potential applications of $\delta^{18} \mathrm{O}_{\mathrm{P}}$ to marine systems where the water $\delta^{18} \mathrm{O}$ background remains constant, but temperature does not. For example, when a $\mathrm{P}_{\mathrm{i}}$-water system is perturbed by a change in temperature (diurnal or seasonal), $\delta^{18} \mathrm{O}_{\mathrm{W}}$, or $\delta^{18} \mathrm{O}_{\mathrm{P}}$ of the $\mathrm{P}$ pool (for example, $\mathrm{P}_{\mathrm{i}}$ vs. $\mathrm{P}_{\text {org }}$, nutrient upwelling, artificial addition of a $\mathrm{P}_{\mathrm{i}} / \mathrm{P}_{\text {org }}$ spike), the rate of rebound to equilibrium conditions can be an indication of $\mathrm{P}_{\mathrm{i}}$ flux and turnover rates (Colman, ms, 2002). 


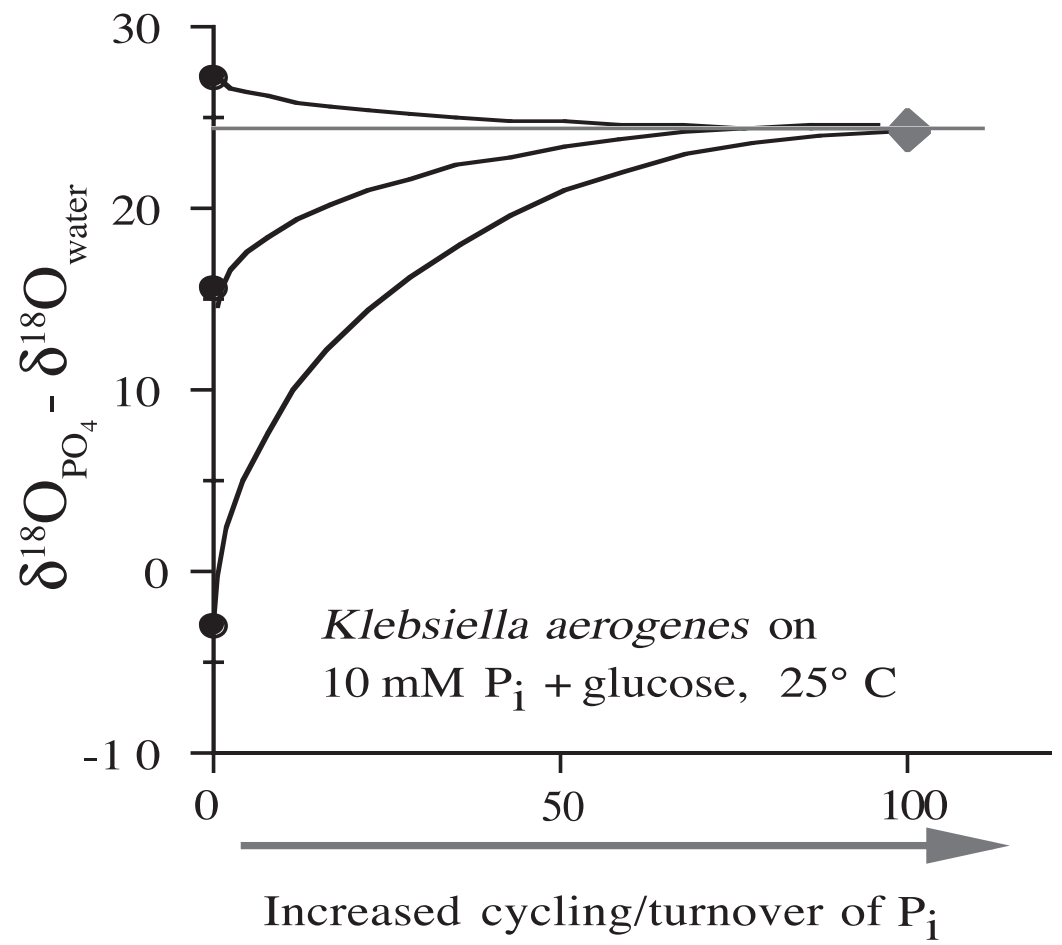

Fig. 10. $\mathrm{P}_{\mathrm{i}}$ turnover and evolution of extracellular $\mathrm{P}_{\mathrm{i}} \delta^{18} \mathrm{O}_{\mathrm{P}}$ in $3{ }^{18} \mathrm{O}$-labeled waters. Note approach to equilibrium from opposite directions (heavy offset from 20 permil equilibrium due to incomplete uptake of excess $\mathrm{P}_{\mathrm{i}}$, creating a heavy residual $\mathrm{P}_{\mathrm{i}}$ pool. Initial $\delta^{18} \mathrm{O}_{\mathrm{P}} \sim+11$ permil and $\delta^{18} \mathrm{O}_{\mathrm{W}}$ remained constant throughout the duration of the experiment.

The conservative tracer properties of $\delta^{18} \mathrm{O}_{\mathrm{P}}$ result from incomplete turnover/ resetting of source $\mathrm{P}_{\mathrm{i}}$ (Markel and others, 1994), or inheritance isotope effects accompanying regeneration of $\mathrm{P}_{\mathrm{i}}$ from $\mathrm{P}_{\text {org }}$ by APase and other phosphomonoesterases with similar reaction mechanisms (Liang and Blake, 2002; Liang, ms, 2005). Thus, $\delta^{18} \mathrm{O}_{\mathrm{P}}$ may be used to determine if $\mathrm{P}_{\text {org }}$ or $\mathrm{P}_{\mathrm{i}}$ is being used to support primary productivity, and how $\mathrm{P}_{\text {org }}$ is being used (for example, as a $\mathrm{P}$ source or $\mathrm{C}$ and $\mathrm{N}$ source). Inheritance effects are expected to persist only in systems where $\mathrm{P}_{\mathrm{i}}$ is regenerated from $\mathrm{P}_{\text {org }}$ and not subsequently taken up and turned over further by biota, that is, under conditions of $\mathrm{P}_{\mathrm{i}}$ excess. The best case would be one where $\mathrm{P}_{\text {org }}$ or $\mathrm{P}_{\mathrm{i}}$ is derived from exogenous sources with different $\delta^{18} \mathrm{O}_{\mathrm{W}}$ and/or temperature characteristics, such as during terrestrial $\mathrm{P}_{\text {org }}$ input to a marine system at high latitudes; or during $\mathrm{P}$ cycling in hydrothermal systems with steep temperature gradients. Under such conditions there will be large differences between the isotopic composition of inherited $\mathrm{P}_{\text {org }}$ oxygen and oxygen introduced from ambient water. The sustained presence of dissolved $\mathrm{P}_{\mathrm{i}}$ with an inheritance oxygen isotope signature would indicate conditions of slow $\mathrm{P}_{\mathrm{i}}$ turnover or $\mathrm{P}_{\mathrm{i}}$ excess, which would point to limitation of primary productivity by other nutrients such as $\mathrm{C}, \mathrm{N}$ or $\mathrm{Fe}$. Interpretation of $\delta^{18} \mathrm{O}_{\mathrm{P}}$ values of inherited $\mathrm{O}$ in $\mathrm{PO}_{4}$ requires knowledge of the meaning of $\delta^{18} \mathrm{O}_{\mathrm{P}}$ signatures of $\mathrm{PO}_{4}$ in $\mathrm{P}_{\text {org }}$, specifically the relationship between $\delta^{18} \mathrm{O}_{\mathrm{P}}$ of $\mathrm{P}_{\text {org }}, \delta^{18} \mathrm{O}_{\mathrm{W}}$ and temperature.

Above applications of $\delta^{18} \mathrm{O}_{\mathrm{P}}$ to trace active $\mathrm{P}$ cycling require independent determination of $\delta^{18} \mathrm{O}_{\mathrm{W}}$ and temperature along a flow/reaction path in order to detect $\mathrm{P}_{\mathrm{i}}$-water exchange, relative changes in $\delta^{18} \mathrm{O}_{\mathrm{P}}$, and to provide optimal constraints on the 
system. These conditions would seem to limit $\delta^{18} \mathrm{O}_{\mathrm{P}}$ applications to modern systems, but if appropriate proxies for temperature and $\delta^{18} \mathrm{O}_{\mathrm{W}}$ can be established, $\delta^{18} \mathrm{O}_{\mathrm{P}}$ may have applications to ancient and extraterrestrial systems as well (Greenwood and others, 2003). Even without $\delta^{18} \mathrm{O}_{\mathrm{W}}$ and temperature constraints, $\delta^{18} \mathrm{O}_{\mathrm{P}}$ anomalies may indicate hydrothermal activity or $\mathrm{P}_{\mathrm{i}}$-water exchange, which at low temperature, is catalyzed only by enzymes. It is emphasized here that the experimental results and applications described in this paper and dynamic nature of $\delta^{18} \mathrm{O}_{\mathrm{P}}$ apply to $\delta^{18} \mathrm{O}_{\mathrm{P}}$ of $\mathrm{P}_{\mathrm{i}}$ (dissolved $\mathrm{PO}_{4}$ ) and should not be confused with $\delta^{18} \mathrm{O}_{\mathrm{P}}$ of biogenic apatites, which is a robust recorder of paleoenvironmental conditions.

Recent applications of $\delta^{18} O_{P}$ in natural systems. - Improved techniques for the measurement of $\delta^{18} \mathrm{O}_{\mathrm{P}}$ values of seawater $\mathrm{P}_{\mathrm{i}}$ are now available (Colman and others, 2000; Colman, ms, 2002; McLaughlin and others, 2004; Colman and others, 2005). Studies of $\delta^{18} \mathrm{O}_{\mathrm{P}}$ in groundwater (Blake and others, 2001), rivers and municipal wastewater systems (Moreira and others, 2000; Colman, ms, 2002) and deep-sea porewaters using improved sample handling/storage and analytical techniques, support the above experimental results on PPase and APase. Equilibrium to near-equilibrium temperaturedependent $\mathrm{P}_{\mathrm{i}}$-water $\mathrm{O}$ isotope fractionations have been observed on large scales in most natural systems studied thus far (Liang, ms, 2005). Phosphate in systems with high $\mathrm{P}_{\mathrm{i}}$ concentrations or $\mathrm{P}_{\mathrm{i}}$ excess are shifted toward more negative $\delta^{18} \mathrm{O}_{\mathrm{P}}$ values which, in the case of the deep marine water column, is consistent with kinetic fractionations produced by APase during regeneration of $\mathrm{P}_{\mathrm{i}}$ from organic matter. As mentioned above, $\mathrm{P}_{\mathrm{i}}$ can also be adsorbed by sediments and could then transfer $\delta^{18} \mathrm{O}_{\mathrm{P}}$ signatures to sedimentary phases. Iron-oxide deposits formed by deep-sea hydrothermal venting are efficient scavengers of phosphate from seawater (Berner, 1973; Wheat and others, 1996). Phosphate extracted from hydrothermal iron-oxide deposits along the East Pacific Rise has $\delta^{18} \mathrm{O}_{\mathrm{P}}$ values that also reflect isotopic equilibrium with ambient water and temperature conditions and points to the dominance of PPase isotope effects in these sediments (Blake and others, 2001). Whether PPase signatures in Fe-oxide- $\mathrm{PO}_{4}$ deposits are derived from ambient water $\mathrm{P}_{\mathrm{i}}$, or from in situ enzymatic/ microbial activity, is currently being investigated.

CONCLUSIONS

A series of laboratory experiments were performed to determine the oxygen isotope fractionations between dissolved inorganic $\mathrm{PO}_{4}$ and water associated with biogeochemical P cycling. Results of experiments with single, cell-free enzymes as well as microbial cultures indicate that the $\mathrm{PO}_{4}$ system is characterized by multiple isotope effects including equilibrium, kinetic, and inheritance effects. Dominance of one isotope effect over the others can be related to growth conditions, the concentrations and sources of $\mathrm{P}\left(\mathrm{P}_{\mathrm{i}}\right.$ or $\left.\mathrm{P}_{\text {org }}\right)$, and specific enzymatic/cellular processes at work in the system. Inorganic pyrophosphatase is the enzyme that catalyzes temperaturedependent equilibrium oxygen isotope fractionations between phosphates and water in biological systems and appears to dominate the $\delta^{18} \mathrm{O}$ signature of dissolved phosphate in most natural aquatic systems studied thus far, in spite of potential complexities. Alkaline phosphatase, a key enzyme involved in $\mathrm{P}_{\mathrm{i}}$ regeneration in aquatic systems, catalyzes hydrolysis of phosphomonoesters accompanied by disequilibrium (kinetic and inheritance) isotope effects in released $\mathrm{P}_{\mathrm{i}}$, and uptake of $\mathrm{P}_{\mathrm{i}}$ by intact cells is accompanied by a kinetic isotope effect. These disequilibrium isotope effects are expected only in natural systems with excess $\mathrm{P}_{\mathrm{i}}$, such as contaminated or municipal wastewater systems, or where $\mathrm{P}_{\mathrm{i}}$-regeneration from organic matter dominates phosphate recycling by biota. This is not the case for most natural systems, which are characterized by low concentrations of $\mathrm{P}_{\mathrm{i}}$ and intense phosphate recycling. Results of our experiments point to clear links between specific enzymatic reactions and specific isotope effects. Thus, laboratory-determined isotope effects reported herein may be 
used to interpret $\delta^{18} \mathrm{O}_{\mathrm{P}}$ values and to identify processes controlling $\mathrm{P}$ cycling in natural systems.

\section{ACKNOWLEDGMENTS}

This research was supported by funds provided by: NSF grant EAR-9805659 to REB, Yale University Bateman Fellowship and Hellman Fellowship to REB; and the Woodrow Wilson National Faculty Fellowship to REB and NSF grant EAR9406067 to JRO. Isotopic analyses were performed at the Earth System Center for Stable Isotope Studies (ESCSIS) of the Yale Institute for Biospheric Studies. We thank Paul Aharon, Ellery Ingall and an anonymous reviewer for their reviews, which improved the final manuscript.

\section{REFERENCES}

Aharon, P., and Fu, B., 2000, Microbial sulfate reduction rates and sulfur and oxygen isotope fractionation at oil and gas seeps in deepwater Gulf of Mexico: Geochimica et Cosmochimica Acta, v. 64, p. 233-246.

Ammerman, J. W., 1991, Role of ecto-phosphohydrolases in phosphorus regeneration in estuarine and coastal ecosystems, in Chrost, R., editor, Microbial enzymes in aquatic environments: New York, Springer-Verlag, p. 165-185.

Ammerman, J. W., and Azam, F., 1985, Bacterial 5'-nucleotidase in aquatic ecosystems: A novel mechanism of phosphorus regeneration: Science, v. 227, p. 1338-1340.

Benitez-Nelson, C. R., 2000, The biogeochemical cycling of phosphorus in marine systems: Earth Science Reviews, v. 51, p. 109-135.

Benitez-Nelson, C., and Buesseler, K. O., 1999, Variability of inorganic and organic phosphorus turnover rates in the coastal ocean: Nature, v. 398, p. 502-505.

Berner, R. A., 1973, Phosphate removal from seawater by adsorption on volcanogenic ferric oxides: Earth and Planetary Science Letters, v. 18, p. 77-86.

Bjorkman, K., and Karl, D. M., 2003, Bioavailability of dissolved organic phosphorus in the euphotic zone at Station ALOHA, North Pacific Subtropical Gyre: Limnology and Oceanography, v. 48, p. 1049-1057.

Blake, R. E., O’Neil, J. R., and Garcia, G. A., 1997, Oxygen isotope systematics of microbially mediated reactions of phosphate I.: Degradation of organophosphorus compounds: Geochimica et Cosmochimica Acta, v. 61, p. 4411-4422.

- 1998a, Effects of microbial activity on the $\delta^{18} \mathrm{O}_{\mathrm{p}}$ of dissolved inorganic phosphate and textural features of synthetic apatites: American Mineralogist, v. 83, p. 1516-1531.

— 1998b, Enzyme-catalyzed oxygen isotope exchange between inorganic phosphate and water: Reaction rates and temperature dependence at 5.7-30 ${ }^{\circ} \mathrm{C}$ : Mineralogical Magazine, v. 62A, p. 163-164.

Blake, R. E, Alt, J. C., and Martini, A. M., 2001, Oxygen isotope ratios of $\mathrm{PO}_{4}$ : an inorganic indicator of enzymatic activity and P metabolism and a new biomarker in the search for life: Proceedings of the National Academy of Sciences, Astrobiology Special Feature, v. 98, p. 2148-2153.

Blake, R. E., Surkov, A. V., Böttcher, M. E., Ferdelman, T. G., and Jørgensen, B. B., 2004, Oxygen isotope composition of dissolved sulfate in deep-sea sediments: Eastern Equatorial Pacific Ocean: ODP Scientific Results, v. 201.

Böttcher, M. E., Brumsack, K. H. J., and De Lange, G. J., 1998, Sulfate reduction and related stable isotope $\left({ }^{34} \mathrm{~S},{ }^{18} \mathrm{O}\right)$ variations in interstitial waters of the eastern Mediterranean, in Robertson, A. H. F., and others, editors: Proceedings Ocean Drilling Program, Scientific Results, v. 160: 365-373.

Böttcher, M. E., Bernasconi, S. M., and Brumsack, H. J., 1999, Carbon, sulfur and oxygen isotope geochemistry of interstitial waters from the Western Mediterranean: Proceedings Ocean Drilling Program, Scientific Results, v. 161, p. 413-421.

Broecker, W., and Peng, T. S., 1982, Tracers in the sea: Palisades, New York, Eldigio Press, p. 690.

Brunner, B., Bernasconi, S. M., Kleikemper, J., and Schroth, M. H., 2005, A model for oxygen and sulfur isotope fractionation in sulfate during bacterial sulfate reduction processes: Geochimica et Cosmochimica Acta, v. 69, p. 4773-4785.

Chen, J., Brevet, A., Fromant, M., Leveque, F., Schmitter, J., Blanquet, S., and Plateau, P., 1990, Pyrophosphatase is essential for growth of Escherichia coli: Journal of Bacteriology, v. 172, p. 5686-5689.

Clark, L. L, Ingall, E. D., and Benner, R., 1998, Marine phosphorus is selectively remineralized: Nature, v. 393, p. 426.

Clark, L. L, Ingall, E. D., and Benner, R., 1999, Marine organic phosphorus cycling: Novel insights from nuclear magnetic resonance: American Journal of Science, v. 299, 724-737.

Cohn, M., 1953, A study of oxidative phosphorylation with ${ }^{18}$ O-labeled inorganic phosphate: Journal of Biological Chemistry, v. 201, p. 735-750.

Cohn, M., and Urey, H. C., 1938, Oxygen isotope exchange reactions of organic compounds and water: Journal of the American Chemical Society, v. 60, p. 679-682.

Colman, A. S., ms, 2002, The oxygen isotope composition of dissolved inorganic phosphate and the marine phosphorus cycle: Ph.D. thesis, New Haven, Yale University, 230 p.

Colman, A. S., Karl, D. M., Fogel, M. L., and Blake, R. E., 2000, A new technique for the measurement of phosphate oxygen isotopes of dissolved inorganic phosphate in natural waters: EOS, Transactions, American Geophysical Union 81, v. 47, Fall Meeting Supplement, p. T62C-17. 
Colman, A. S., Blake, R. E., Karl, D. M., Fogel, M. L., and Turekian, K. K., 2005, Marine phosphate oxygen isotopes and organic matter remineralization in the oceans: Proceedings of the National Academy of Science, v. 102, p. 13023-13028.

Cooperman, B. S., 1982, The mechanism of action of yeast inorganic pyrophosphatase: Methods in Enzymology, v. 87, p. 526-548.

Cooperman, B. S., Baykov, A. A., and Lahti, R., 1992, Evolutionary conservation of the active site of soluble inorganic pyrophosphatase: Trends in Biochemical Science, v. 7, p. 262-266.

Cotner, J. B., Ammerman, J. W., Peele, E. R., and Bentzen, E., 1997, Phosphorus-limited bacterioplankton growth in the Sargasso Sea: Aquatic Microbiology and Ecology, v. 13, p. 141-149.

Feuillade, M., and Dorioz, J. M., 1992, Enzymatic release of phosphate in sediments of various origins: Water Research, v. 26, p. 1195-1201.

Fricke, H., and O'Neil, J. R., 1996, Intra-and inter-tooth variation in the oxygen isotope composition of mammalian tooth enamel: Some implications for paleoclimatological and paleobiological research: Palaeogeography, Palaeoclimatology, Palaeoecology, v. 126, p. 91-99.

Fritz, P., Basharmal, G. M., Drimmie, R. J., Ibsen, J., and Qureshi, R. M., 1989, Oxygen isotope exchange between sulphate and water during bacterial sulphate reduction: Chemical Geology, v. 79, p. 99-105.

Goldhaber, M. B., and Kaplan, I. R., 1974, The sulfur cycle, in Goldberg, E. D., editor, The Sea: New York, John Wiley and Sons, v. 5, chapter 17, p. 569-655.

Greenwood, J. P., Blake, R. E., and Coath, C. D., 2003, Ion microprobe measurements of ${ }^{18} \mathrm{O} /{ }^{16} \mathrm{O}$ ratios of phosphate minerals in the Martian meteorites ALH84001 and Los Angeles: Geochimica et Cosmochima Acta, v. 67, p. 2289-2298.

Hellweger, F. L., Farley, K. J., Lall, U., and Di Toro, D. M., 2003, Greedy algae reduce arsenite: Limnology and Oceaonography, v. 48, p. 2275-2288.

Hirschler, A., Lucas, J., and Hubert, J., 1990, Bacterial involvement in apatite genesis: FEMS Microbial Ecology, v. 73, p. 211-220.

Hoppe, H. G., and Ullrich, S., 1999, Profiles of ectoenzymes in the Indian Ocean: phenomena of phosphatase activity in the mesopelagic zone: Aquatic Microbial Ecology, v. 19, p. 139-148.

Hudson, J. J., Taylor, W. T., and Schindler, D. W., 2000, Phosphate concentrations in lakes: Nature, v. 406, p. 54-56.

Janson, C., Degani, C., and Boyer, P. D., 1979, The formation of enzyme-bound and medium pyrophosphate and the molecular basis of the oxygen exchange reaction of yeast inorganic pyrophosphatase: Journal of Biological Chemistry, v. 254, p. 3743-3749.

Karl, D. M., 2000, Phosphorus, the staff of life: Nature, v. 406, p. 31-32.

Karl, D. M., and Bjorkman, K., 2002, Dynamics of DOP, in Hansell, D. A., and Carlson, C. C., editors, Biogeochemistry of marine dissolved organic matter: Boston, Academic Press, p. 249-366.

Karl, D. M., and Yanagi, K., 1997, Partial characterization of the dissolved organic phosphorus pool in the oligotrophic North Pacific Ocean: Limnology and Oceanography, v. 42, p. 1398-1405.

Kolodny, Y., Luz, B., and Navon, O., 1983, Oxygen isotope variations in phosphate of biogenic apatites, I. Fish bone apatite-rechecking the rules of the game: Earth and Planetary Science Letters, v. 64, p. 398-404.

Kolowith, L. C., Ingall, E. D., and Benner, R., 2001, Composition and cycling of marine organic phosphorus: Limnology and Oceanography, v. 46, p. 309-320.

Kornexl, B. E., Gehre, M., Hofling, R., and Werner, R. A., 1999, On-line $\delta^{18} \mathrm{O}$ measurement of organic and inorganic substances: Rapid Communications in Mass Spectrometry, v. 13, p. 1685-1693.

Koroleff, F., 1983, Determination of phosphorus, in Grasshoff, K., and Kremling, M., editors, Methods of Seawater Analysis, 2nd edition: New York, Verlag Chemie, p. 125-187.

Krom, M. D., Herut, B., and Mantoura, R. F. C., 2004, Nutrient budget for the Eastern Mediterranean: Implications for phosphorus limitation: Limnology and Oceanography, v. 49, 1582-1592.

Kunitz, M., 1951, Crystalline inorganic pyrophosphatase isolated from Baker's yeast: Journal of General Physiology, v. 35, p. 423-450.

Larkaamp, K. L., ms, 2000, Organic phosphorus in marine sediments: Chemical structure, diagenetic alteration, and mechanisms of preservation: Massachusetts, Ph.D. thesis, MIT/WHOI Joint Program in Oceanography, $286 \mathrm{p}$.

Lécuyer, C., Grandjean, P., and Emig, C. C., 1996, Determination of oxygen isotope fractionation between water and phosphate from living lingulids: Potential application to paleoenvironmental studies: Palaeogeography, Palaeoclimatology, Palaeoecology, v. 126, p. 101-108.

Leppanen, V. M., Nummelin, H., Hansen, T., Lahti, R., Schafer, G., and Goldman, A., 1999, Sulfolobus acidocaldarius inorganic pyrophosphatase: structure, thermostability, and effect of metal ion in an archaeal pyrophosphatase: Protein Science, v. 8, p. 1218-1231.

Liang, Y., ms, 2005, Oxygen isotope studies of biogeochemical phosphorus cycling: New Haven, Connecticut, Ph.D. thesis, Yale University, 238 p.

Liang, Y., and Blake, R. E., 2002, Oxygen isotope effects of enzyme-catalyzed organophosphorus hydrolysis reactions: implications for interpretation of dissolved $\mathrm{PO}_{4} \delta^{18} \mathrm{O}$ values in natural watersL: EOS, Transactions, American Geophysical Union, 83, Fall Meeting Supplement, Abstract OS21B-0203 (2002).

Longinelli, A., 1984, Oxygen isotopes in mammal bone phosphate: A new tool for paleohydrological and paleoclimatological research?: Geochimica et Cosmochimica Acta, v. 48, p. 385-390.

Longinelli, A., and Nuti, S., 1973, Revised phosphate-water isotopic temperature scale: Earth and Planetary Science Letters, v. 19, p. 373-376.

Longinelli, A., Bartelloni, M., and Cortecci, G., 1976, The isotopic cycle of oceanic phosphate, I: Earth and Planetary Science Letters, v. 32, p. 389-392. 
Lucas, J., and Prévôt, L., 1984, Synthèse de l'apatite par voie bacterienne á partir de matière organique phosphatée et de divers carbonates de calcium dans des eaux douces et marines naturelles: Chemical Geology, v. 42, p. 101-118.

Luz, B., and Kolodny, Y., 1985, Oxygen isotope variations in phosphate of biogenic apatites IV. Mammal teeth and bones: Earth and Planetary Science Letters, v. 75, p. 29-36.

Maloney, P., 1992, The molecular and cell biology of anion transport by bacteria: BioEssays, v. 14, p. 757-762.

Markel, D., Kolodny, Y., Luz, B., and Nishri, A., 1994, Phosphorus cycling and phosphorus sources in Lake Kinneret: Tracing by oxygen isotopes in phosphate: Israel Journal of Earth Sciences, v. 43, p. 165-178.

McLaughlin, K., Silva, S., Kendall, C., Stuart-Williams, H., and Paytan, A., 2004, A precise method for the analysis of $\delta^{18} \mathrm{O}$ of dissolved inorganic phosphate in seawater: Limnology and Oceanography: Methods, v. 2, p. 202-212.

Metcalf, W. W., and Wolfe, R. S., 1998, Molecular Genetic Analysis of Phosphite and Hypophosphite Oxidation by Pseudmonas stutzeri WM88: Journal of Bacteriology, v. 180, p. 5547-5558.

Mitzutani, Y., and Rafter, T. A., 1973, Isotopic behavior of sulphate oxygen in the bacterial reduction of sulphate: Geochemical Journal, v. 6, p. 183-191.

Moreira, N. F., Martini, A. M., and Blake, R. E., 2000, Biogeochemical degradation of phosphate in a contaminated sand and gravel aquifer, Cape Cod, Massachusetts: Geological Society of America, Northeastern Section Meeting, New Brunswick, New Jersey, abstract.

Nawrocki, M. P., and Karl, D. M., 1989, Dissolved ATP turnover in the Bransfield Strait, Antarctica during the spring bloom: Marine Ecology Program Series, v. 57, p. 35-44.

O’Neil, J. R., Roe, L. J., Reinhard, E., and Blake, R. E., 1994, A rapid and precise method of oxygen isotope analysis of biogenic phosphate: Israel Journal of Earth Science, v. 43, p. 203-212.

Paytan, A., Kolodny, Y., Neori, A., and Luz, B., 2002, Rapid biologically mediated oxygen isotope exchange between water and phosphate: Global Biogeochemical Cycles, v. 16, p. 13-1-13-7.

Paytan, A., Cade-Menum, B. J., McLaughlin, K, and Faul, K. L., 2003, Selective phosphorus regeneration of sinking marine particles: Evidence from ${ }^{31}$ P NMR: Marine Chemistry, v. 82, p. 55-70.

Pfennig, N., and Lippert, R. D., 1966, Uber das Vitamin $\mathrm{B}_{12}$-Bedurfnis phototropher Schwefelbacterien: Archives of Microbiology, v. 55, p. 245-256.

Pohjanjoki, P., Lahti, R., Goldman, A., and Cooperman, B. S., 1998, Evolutionary conservation of enzymatic catalysis: quantitative comparison of the effects of mutation of aligned residues in Saccharomyces cerevisiae and Escherichia coli inorganic pyrophosphatases on enzymatic activity: Biochemistry, v. 37, p. 1754-61.

Rayleigh, J. W. S., 1896, Theoretical considerations respecting the separation of gases by diffusion and similar processes: Philosophical Transactions of the Royal Society of London, v. 42, p. 493-498.

Rees, C. E., 1973, A steady-state model for sulphur isotope fractionation in bacterial reduction processes: Geochimica et Cosmochimica Acta, v. 37, p. 1141-1162.

Rosenberg, H., Lesley, M. R., Jacomb, P. A., and Chegwidden, K., 1982, Phosphate exchange in the Pit transport system in Escherichia coli: Journal of Bacteriology, v. 149, p. 123-130.

Sañudo-Wilhelmy, S. A., Kustka, A. B., Gobler, C. J., Hutchins, D. A., Yang, M., Lwiza, K., Burns, J., Capone, D. G., Raven, J. A., and Carpenter, E. J., 2001, Phosphorus limitation of nitrogen fixation by Trichodesmium in the central Atlantic Ocean: Nature, v. 411, p. 66-69.

Schink, B., and Friedrich, M., 2000, Phosphite oxidation by sulphate reduction: Nature, v. 406, p. 37.

Schink, B., Volker, T., Helke, L., and Friedrich, M. W., 2002, Desulfotignum phosphitoxidans sp. nov., a new marine sulfate reducer that oxidizes phosphite to phosphate: Archives of Microbiology, v. 177, p. 381391.

Sharp, Z., and Cerling, T. E., 1996, A laser GC-IRMS technique for the in situ stable isotope analyses of carbonates and phosphates: Geochimica et Cosmochimica Acta, v. 60, p. 2909-2916.

Smith, S. V., Kimmerer, J., and Walsh, T. W., 1986, Vertical flux and biochemical turnover regulate nutrient limitation of net organic production in the North Pacific Gyre: Limnology and Oceanography, v. 31, p. 161-167.

Suida, W., and Güde, H., 1994, A comparitive study on $5^{\prime}$-nucleotidase (5'-nase) and alkaline phosphatase (APA) activities in two lakes: Archives of Hydrobiology, v. 131, p. 211-229.

Sundareshwar, P. V., Morris, J. T., Koepfler, E. K., and Fornwalt, B., 2003, Phosphorus limitation of coastal ecosystem processes: Science, v. 299, p. 563-565.

Torriani-Gorini, A., Yagil, E., and Silver, S., 1994, in Phosphate in Microorganisms: Cellular and molecular biology: Washington D. C., American Society for Microbiology, p. 1-4.

Van Veen, H. W., 1997, Phosphate transport in prokaryotes: molecules, mediators and mechanisms: Antoine van Leeuwenhoek, v. 72, p. 299-315.

Vennemann, T. W., Fricke, H. C., Blake, R. E., and O’Neil, J. R., 2002, Oxygen isotope analysis of phosphates: A comparison of techniques for analyses of $\mathrm{Ag}_{3} \mathrm{PO}_{4}$ : Chemical Geology, v. 185, p. 321-336.

Walsh, C., 1979, Enzymatic Reaction Mechanisms: San Francisco, California, W. H. Freeman Co., p. $202-204$.

Wheat, C. G., Feely, R. A., and Mottl, M. J., 1996, Phosphate removal by oceanic hydrothermal processes: an update of the phosphorus budget in the oceans: Geochimica et Cosmochimica Acta, v. 60, p. 35933608 .

Wu, J. F., Sunda, E. A., Boyle, E. A., and Karl, D. M., 2000, Phosphate depletion in the western North Atlantic Ocean: Science, v. 289, p. 759-762. 